\title{
DISTRIBUTION OF BOTTOM SEDIMENTS ON THE CONTINENTAL SHELF, NORTHERN BERING SEA
}

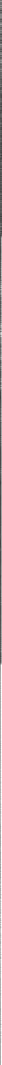





\section{Distribution of Bottom Sediments on the Continental Shelf, Northern Bering Sea}

By Dean A. McManus, Venkatarathnam Kolla

David M. Hopkins, and C. Hans Nelson

STUDIES ON THE MARINE GEOLOGY OF THE BERING SEA

GEOLOGICA L S URVEY PROFESSIONAL PAPER 75 9-C

Prepared in cooperation with Department of

Oceanography, University of Washington

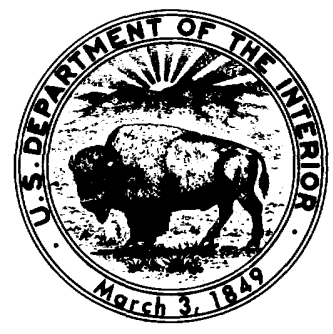




\section{UNITED STATES DEPARTMENT OF THE INTERIOR}

CECIL D. ANDRUS, Secretary

\section{GEOLOGICAL SURVEY}

V. E. McKelvey, Director

Library of Congress Cataloging in Publication Data

Main entry under title:

Distribution of bottom sediments on the Continental Shelf, Northern Bering Sea.

(Studies on the marine geology of the Bering Sea)

(Geological Survey professional paper ; 759-C)

Bibliography: p.

1. Marine sediments--Bering Sea. 2. Ocean currents--Bering Sea. I. McManus, Dean A. II. Washington (State). University. Dept. of Oceanography. III. Columbia University. Geological Observatory. IV. Series. V. Series: United States. Geological Survey. Professional paper ; 759-C

GC398.5.D57 551.4'65'51 76-608367

For sale by the Superintendent of Documents, U.S. Government Printing Office Washington, D.C. 20402

Stock Number 024-001-02993-6 


\section{CONTENTS}

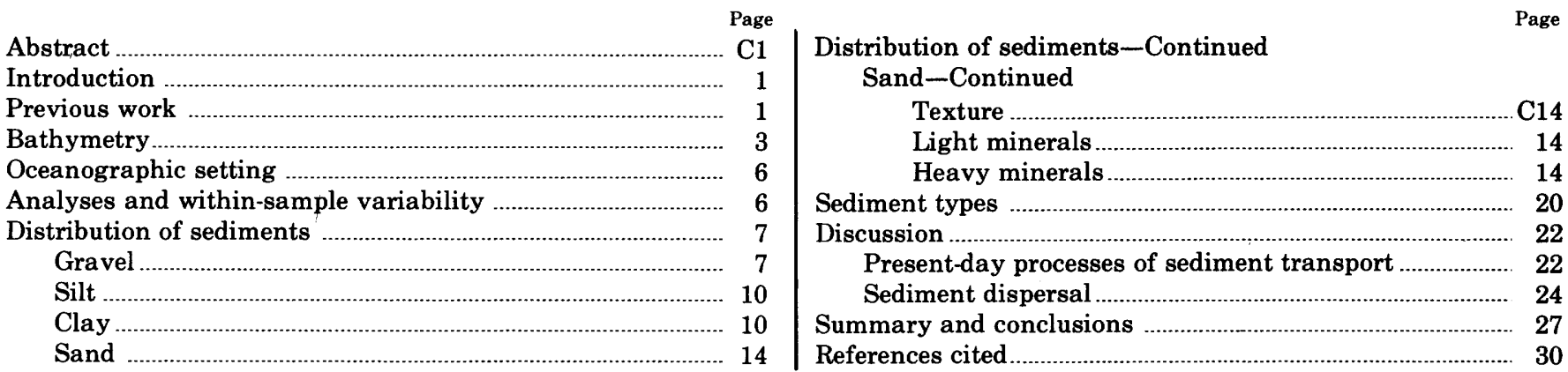

\section{ILLUSTRATIONS}

Figure 1. Index map of continental shelf in northern Bering Sea.

2. Bathymetric chart of northern Bering Sea showing station locations

3-15. Maps of northern Bering Sea showing:

3. Current measurements

4. Generalized geology

5. Gravel distribution

6. Silt distribution

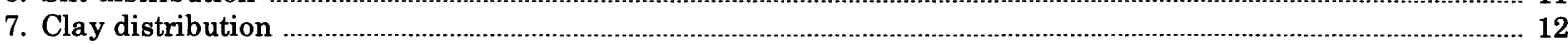

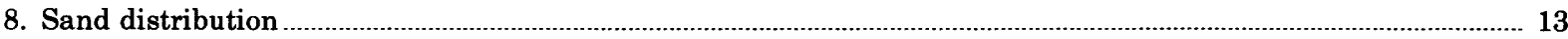

9. Distribution of modal classes of sand

10. Sorting of bottom sediments

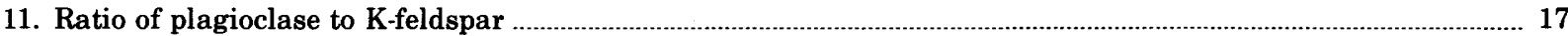

12. Distribution of factors from Q-mode factor analysis of heavy minerals .......................................................... 19

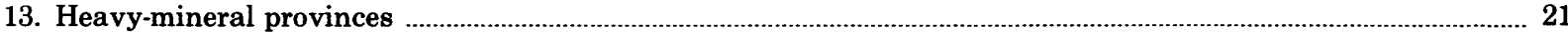

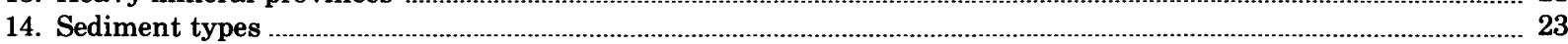

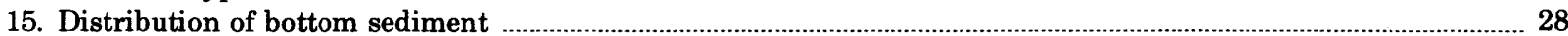

\section{TABLES}

TABLE 1. Variance of texture variables...

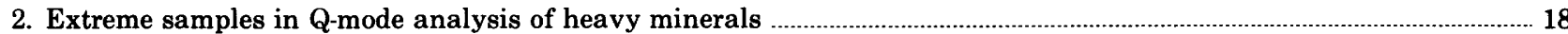

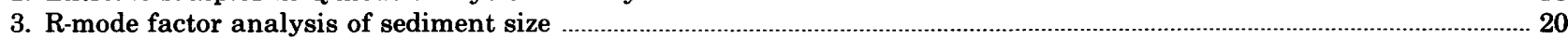

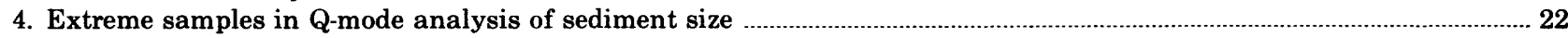




\title{
DISTRIBUTION OF BOTTOM SEDIMENTS ON THE CONTINENTAL SHELF, NORTHERN BERING SEA ${ }^{1}$
}

\author{
By Dean A. McManus, ${ }^{2}$ Venkatarathnam Kolla, ${ }^{3}$ \\ David M. Hopkins, and C. Hans Nelson ${ }^{4}$
}

\begin{abstract}
ABSTRACI
Most of the sediment contributed to the northern Bering Sea today (modern sediment) is associated with the Yukon River runoff and the high-speed currents $(30-40 \mathrm{~cm} / \mathrm{sec}$ near the bottom) within the Alaskan Coastal Water, which sets northward along the coast through Bering Strait into the Chukchi Sea. Most sediment is silt sized but includes some very fine grained sand and clay-sized material. The very fine sand extends northward across the mouth of Norton Sound, where it mixes on the west with relict Yukon fine sand to form a palimpsest sand, thence grades eastward into Yukon silt that covers southern Norton Sound.

Much of the Yukon silt enters Norton Sound, but there is only a thin accumulation there, except near the delta. The silt issues from the sound along the north side, where a silt deposit is in presumed dynamic equilibrium, thereby marking the dispersal path through a depression into the coastal current. The modern silt associated with the coastal current is considered a dynamic component of the bottom sediment, which otherwise consists of relict sand and gravel. The net transport of the silt is through the Bering Strait and into the Chukchi Sea.

Impressed on the steady northward-setting current are irregular large-velocity fluctuations produced partly by tidal currents and partly by the wind regime. For the area as a whole, tidal currents and wind drift are believed to be more significant than wave drift or estuarine-type density circulation.

Where the coastal current is strongest, the sediment is a relict or residual lag sand and gravel derived from glacial material or from metamorphic bedrock of Seward Peninsula. Under the slower Modified Shelf Water offshore of the coastal water, the bottom sediment also is relict, in part relict Yukon sand, in part derived from glacial moraines. Modern sediments do not accumulate beneath the Modified Shelf Water, as they do beneath the coastal water.

Northern Bering Sea was subaerially exposed during the period of eustatically lowered sea level that coincided with the last glaciation. However, the surface sediments provide no indication that the Yukon River has ever drained northward into the Arctic Ocean. Until relatively recent time, the Yukon drained southward into southern Bering Sea. The river mouth has been in its present northern position for only a geologically brief period.

Seaward size grading in relict sands is ascribed to the presentday strong current paralleling the isobaths.
\end{abstract}

\footnotetext{
'Contribution 825 of the Department of Oceanography, University of Washington, based on work done as part of a joint research program by the U.S. Geological Survey and the University of Washington and financed by the U.S. Geological Survey.

2Department of Oceanography, University of Washington, Seattle, Wash. 98105.

"Lamont-Doherty Geological Observatory, Columbia University, Palisades, N.Y. 10964.

${ }^{4}$ U.S. Geological Survey, 345 Middlefield Road, Menlo Park, Calif. 94025.
}

\section{INTRODUCTION}

The continental shelf in the Bering Sea is one of the largest in the world. Even the shallow, northernmost part of the shelf formed by the Chirikov Basin and Norton Sound (fig. 1) covers an area of $11 \times 10^{4} \mathrm{~km}^{2}$, approximately the area of the shelf in the western Gulf of Mexico from the Mississippi Delta to the mouth of the Rio Grande. Yet for the Chirikov Basin and Norton Sound, only a very general picture of the shelf sediments has been available. The purpose of this study is to evaluate the role of modern sedimentary processes in the region and to seek a better definition of sediment provenance. A brief summary of part of this work is given in an earlier work (McManus and others, 1974).

\section{PREVIOUS WORK}

A brief description of the bottom sediments of the Bering Sea and a summary of cruises to the study area prior to 1965 are presented by Creager and McManus (1967), who noted the presence in Norton Sound of modern sediment from the Yukon River but considered the sediment in the Chirikov Basin to be relict. A detailed study by McManus, Kelley, and Creager (1969) concentrated on the Chukchi Sea north of Bering Strait, concluding that the Chirikov Basin sediment was not masked by the modern silts from the Yukon River, as the Yukon sediment was being transported across the basin and into the Chukchi Sea as a turbid layer in the lower part of the water column. Subsequently, the particle size and concentration of suspended material in the water column were measured by McManus and Smyth (1970), further substantiating the significance of this process in transporting silt and clay across the floor of northern Bering Sea.

The identification of silt and sand of Yukon origin is based, incidentally, upon study of the mineralogy and texture of a body of sediment clearly of terrigenous origin that thickens toward the present 


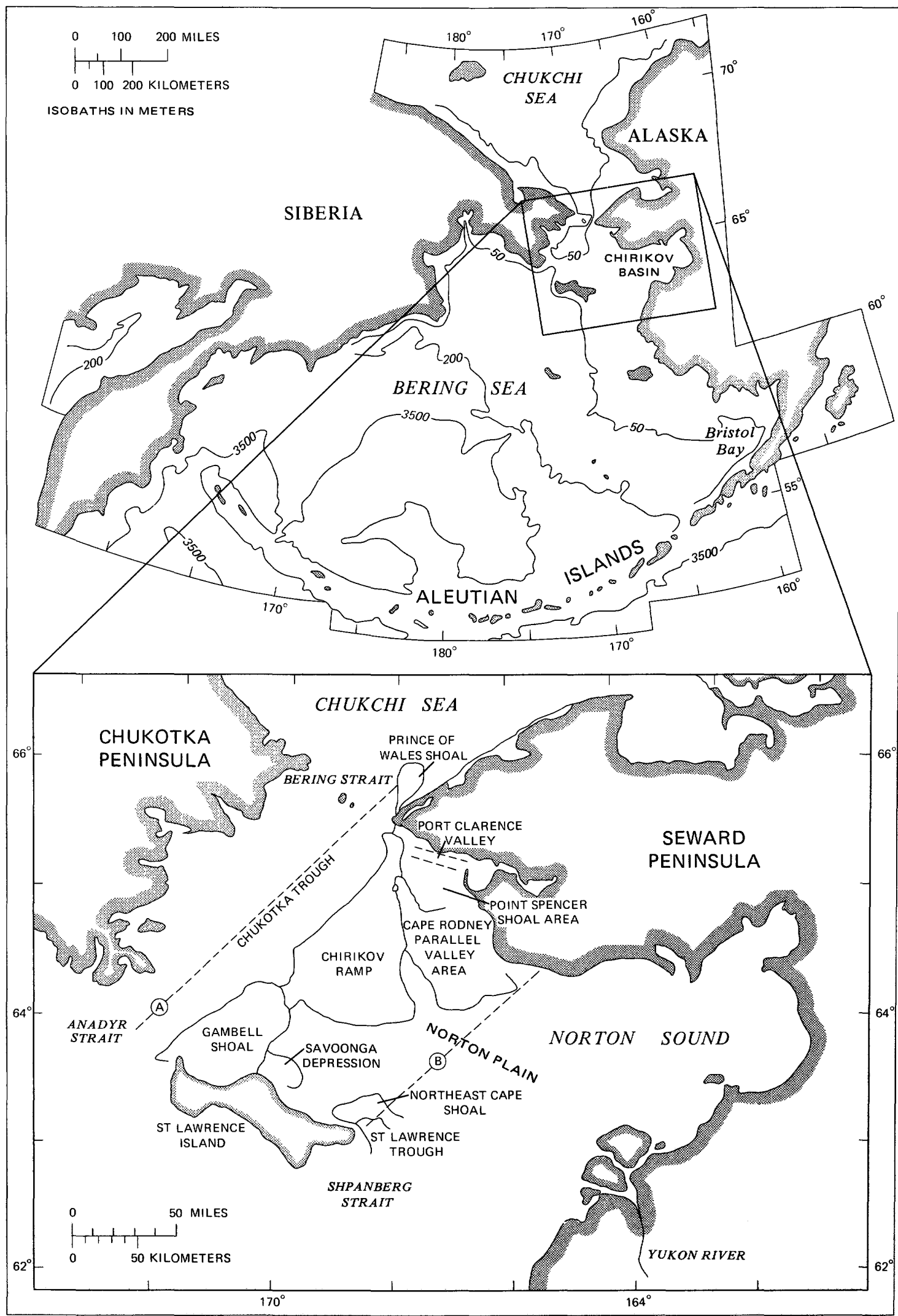


mouth of the Yukon River (McManus and others, 1974). No samples were available to us from within the river itself, and there are as yet no published descriptions of the bed and suspended load of the Yukon River near its mouth.

In order to provide information on the provenance of the sand-sized sediment, a study was begun of the heavy minerals; preliminary results and tabulated data have been presented by Venkatarathnam (1971). Detailed studies of the sediment texture and gold content in the nearshore area off Nome (Nelson and others, 1969; Nelson and Hopkins, 1972) produced a better understanding of the complexities of sediment distribution near the shoreline. Descriptions of sedimentary features recorded by seismic profiling are included in the works of Grim and McManus (1970) and Tagg and Greene (1973). Detailed bathymetric charts of the Chirikov Basin were recently completed (National Ocean Survey Maps 1215-10 [1971], 1714-12 [1973], and 1814-10 [1973]).

\section{BATHYMETRY}

The description of the bathymetry that follows is based upon and uses the physiographic subdivisions proposed by Hopkins, Nelson, Perry, and Alpha (1976) for the Chirikov Basin area.

The water depth in the Chirikov Basin exceeds 50 $m$ in only a few places; in Norton Sound depths are generally less than $20 \mathrm{~m}$ (fig. 2). An average depth for the entire region might be placed at $30 \mathrm{~m}$. Because the depth is shallow and the area large, bottom gradients are very low, even for a continental shelf. The gradient down the Chirikov Ramp (fig. 1) is only $0.1 \mathrm{~m} / \mathrm{km}$ between the $30-\mathrm{m}$ and $50-\mathrm{m}$ isobaths, the relatively steep slope off Nome only $3 \mathrm{~m} / \mathrm{km}$. Nonetheless, within the broad saucer of the study area, small relief features occur that are significant in interpreting the sediment distribution.

The greatest water depths in the study area $(>150 \mathrm{~m})$ are in the fiords along the Chukotka Peninsula; little else is known of the nearshore bathymetry along this coast. Offshore from $\mathrm{Chu}$ -

Figure 1.-Index map of continental shelf in northern Bering Sea showing major physiographic units and sources of bathymetric data for figure 2. Bathymetry west of line $\mathrm{A}$ is contoured from data on U.S. Defense Mapping Agency Hydrographic Center charts. Bathymetry between lines $A$ and $B$ is from National Ocean Survey charts cited in text. Bathymetry east of line B is from (reatuer and McManus (1967). Modified from McManus, Venkataratham, Hopkins, and Nelson (1974). kotka is one of the main bathymetric features, the Chukotka Trough, a shallow depression extending northeastward from Anadyr Strait to the Bering Strait. The deepest part of the trough is a closed depression that terminates northward against a low scarp that lies en echelon with the fault-controlled northern margin of Port Clarence Valley, a prominent sea valley extending parallel to the coast of Seward Peninsula eastward as far as Port Clarence (fig. 1).

A prominent ridge of diverse surface topography, the Gambell Shoal, extends northeastward from the western part of St. Lawrence Island. Farther northeast, the Chukotka Trough is adjoined by the Chirikov Ramp, a gently sloping surface indented by many shallow branching swales suggestive of a northward draining subaerial stream system. The eastern part of the Chirikov Basin and much of Norton Sound is underlain by the Norton Plain, a region of monotonously flat topography that extends eastward to the delta of the Yukon River. A broad, low ridge extending parallel to the coast of $\mathrm{St}$. Lawrence Island diversifies the south western corner of the Norton Plain. The Savoonga Depression, a sharply defined depression with maximum water depths exceeding $50 \mathrm{~m}$, lies off the north-central coast of St. Lawrence Island. Hopkins, Nelson, and Perry (unpub. data, 1973) show that the depression results from the faulting and folding of underlying Tertiary sedimentary rocks but that the bottom topography is diversified by intrusive volcanic plugs and by ridges formed by submarine fissure eruptions of Quaternary age.

A south-trending depression, the St. Lawrence Trough, lies just off the east end of St. Lawrence Island. Water depths in this sea valley exceed $40 \mathrm{~m}$. The presence of fault scarps (Grim and McManus, 1970) and closure of the bathymetric contours suggest that tectonic activity may be involved in the origin of the sea valley, but scouring by strong northsetting currents and stream erosion during intervals of low sea level may have played a role. Northward the St. Lawrence Trough terminates abruptly against a broad constructional ridge, the Northeast Cape Shoal. Other large shoals and depressions trend northward in Shpanberg Strait east of the St. Lawrence Trough.

The floor of Norton Sound is not marked by a continuous gradient away from the Yukon Delta; rather, it contains an east-trending depression separated from the Chirikov Basin by a broad ridge 


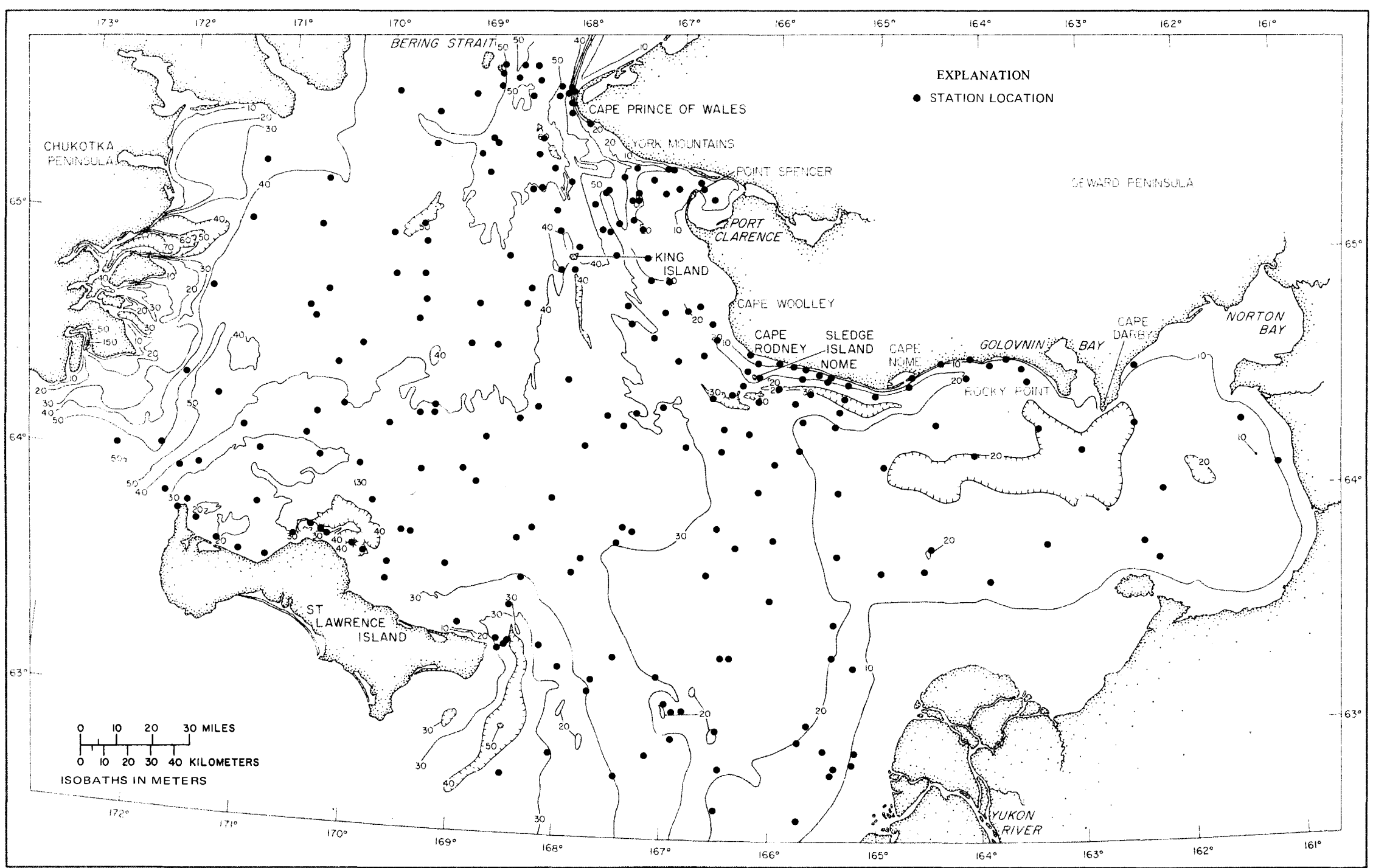

FIGURE 2.-Bathymetric chart of study area showing station locations (McManus and others, 1974). A more detailed bathymetric chart is given by Hopkins, Nelson, Perry, and Alpha (1976). 
extending north from the Yukon River delta. Deep passages extend along the coast off Cape Darby and Rocky Point. Another long, narrow depression off Nome is separated from the central depression by an east-trending shoal.
The region off the coast of Seward Peninsula between Sledge Island, Port Clarence, and King Island constitutes the Cape Rodney Parallel Valley Area, a region of low, widely spaced ridges and troughs trending northwestward. This province is

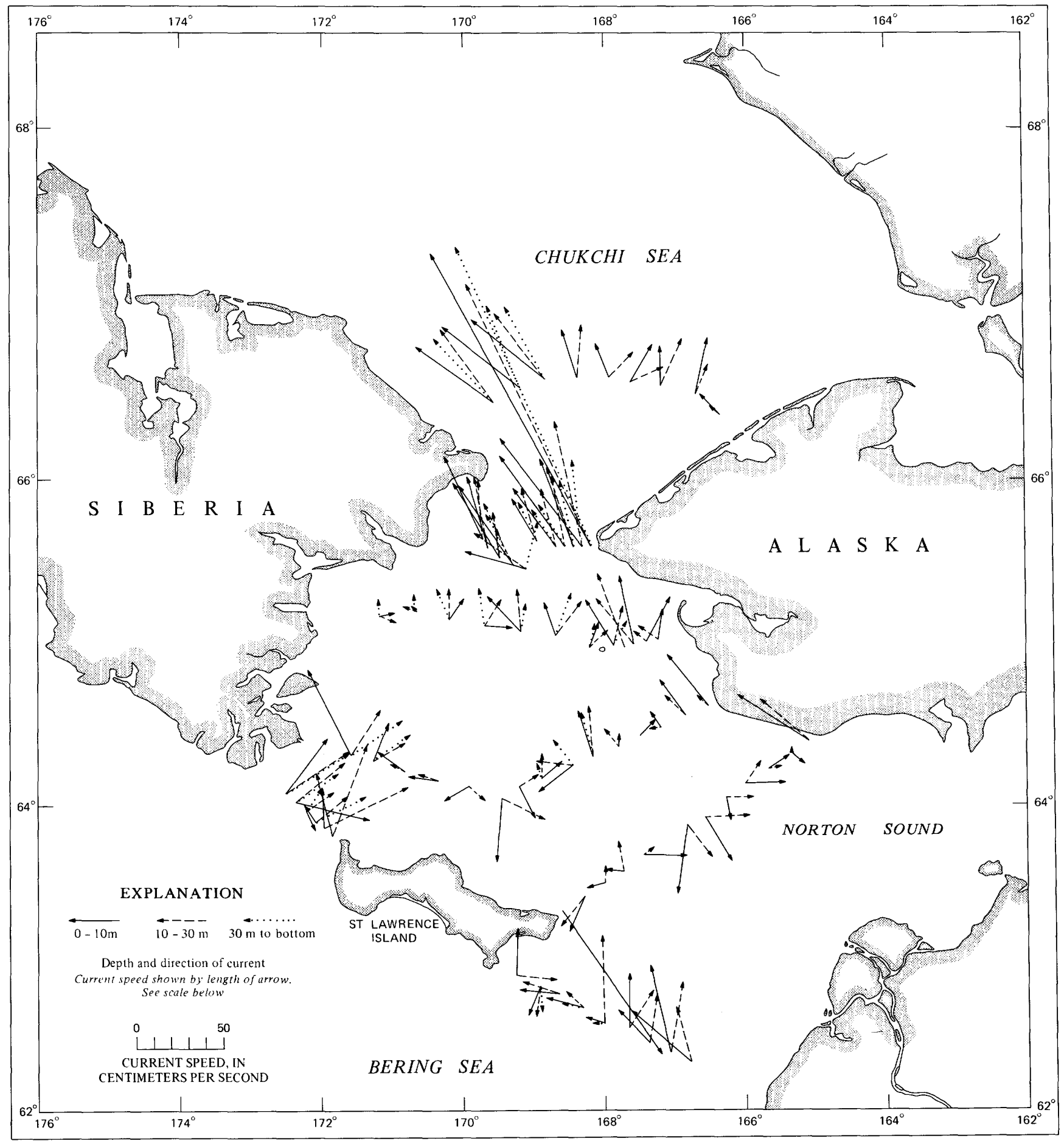

FiguRE 3.-Current measurements during early July 1968. Sites of measurement are at bases of arrows. (After Coachman and others, 1976, with permission of University of Washington Press). 
succeeded to the northwest by the Point Spencer Shoal Area, which contains a series of large constructional shoals having crests at approximately 10,20 , and $30 \mathrm{~m}$. Sand waves occur at about $20 \mathrm{~m}$ depth on the western flanks of the 10-m shoal (Grim and McManus, 1970).

\section{OCEANOGRAPHIC SETTING}

Hydrographic data are available for only the 4month open season, when the hydrographic regime is constituted of warm $\left(>8^{\circ} \mathrm{C}\right)$, less saline $\left(<31^{\circ} / \mathrm{oo}\right)$ water along the Alaska coast, and cold, more saline water offshore. The Alaskan Coastal Water, formed largely by river runoff from the coastal lowland between Bristol Bay and the Yukon River, borders that coast, fills Norton Sound, and again borders the coast from Nome through the Bering Strait and into the Chukchi Sea. Steep horizontal gradients in temperature and salinity mark the boundary with the Modified Shelf Water offshore (see figures in McManus and Creager, 1963, and McManus and others, 1969), which originates in the northern Bering Sea during winter ice formation (Sauer and others, 1954). Although warmed above the $\angle 0^{\circ} \mathrm{C}$ temperatures of the Deep Shelf Water, the Modified Shelf Water is still cold $\left(0^{\circ}-4^{\circ} \mathrm{C}\right)$ and ranges in salinity from 31.5 to $33^{\circ} \%$ oo.

Both the Alaskan Coastal Water and the Modified Shelf Water have a net movement northward through Bering Strait (fig. 3) as a result of a sea-surface slope (Coachman and Aagaard, 1966). The cause of the difference in sea level between the Bering and Chukchi Seas is unknown. At 20-m water depths southeast of Bering Strait, current velocities of $30-50 \mathrm{~cm} / \mathrm{sec}$ have been measured in the coastal water. In the Chirikov Basin, the rates drop to $10-30 \mathrm{~cm} / \mathrm{sec}$. A 19hour anchor station measured velocities of 4-16 $\mathrm{cm} / \mathrm{sec}$ within $1 \mathrm{~m}$ of the bottom in this basin (R. Sternberg, written commun., 1971).

Two types of major velocity fluctuations occur in the persistent northerly setting current. Regular fluctuations of 50-70 percent of the mean velocity appear to have a tidal origin (Coachman and Aagaard, 1966; Coachman and Tripp, 1970). In addition, the general current velocity may fluctuate as much as 100 percent over a period of a day or more, presumably as a result of major changes in atmospheric pressure or the wind regime (Coachman and Tripp, 1970). Winds produce storm surges or setups raising sea level as much as $4 \mathrm{~m}$ along the southern coast of Seward Peninsula (U.S. Coast and Geodetic Survey, 1964).

The generally northward flow of the entire water column has a direct effect on the coastal water where westward-extending promontories deflect the flow (Fleming and Heggarty, 1966). The less dense coastal water is piled up against the shore as a thickened section, and strong currents are produced to move the water, as along southwestern Seward Peninsula. Under these conditions, relatively warm and dilute, high-velocity water in the area between the shore and the eastern boundary of the Chirikov Ramp is set northward. At times when prolonged northerly winds greatly restrict the flow into the Chukchi Sea, however, the coastal water spreads out as a surface layer on the denser Modified Shelf Water rather than occupying the entire water column from the shore of the Seward Peninsula to the Chirikov Ramp.

A more complete bibliography of the physical oceanography is given in McManus, Kelley, and Creager (1969).

\section{ANALYSES AND WITHIN-SAMPLE VARIABILITY}

Samples collected from the stations shown on figure 2 were analyzed for sediment texture by standard sieve and pipette techniques. The approximately 250 samples with complete analysis include those reported on by Creager and McManus (1967) and McManus, Kelley, and Creager (1969). The graphical estimates of Folk and Ward (1957) were used to describe the grain-size distribution.

Of the 204 heavy-mineral separates made by methylene iodide (sp. gr. 3.14-3.17), 120 were examined to identify the minerals in the 1-2.75 $\phi$ and the 2.75-4.00 $\phi$ size fractions. The data on the percent of heavy residue and of individual heavy minerals in each of the two sizes have been reported elsewhere (Venkatarathnam, 1971). Only the $2.75-4.00 \phi$ size fraction is considered in the present paper. Light minerals and pebbles of selected samples were studied by staining and petrographic techniques, respectively.

In order to estimate the significance of these data, it is necessary to have some measure of the variability associated with the data points. Although such measurements can be based upon replicate grab samples at a station and replicate splits of a grab sample, Kelley and McManus $(1969 ; 1970)$ report that most of the variability for stations on the continental shelf off Washington is associated with betweensplits variation within a grab sample, rather than between-grab sample variation within a station.

In the present study, replicate grab samples were not taken, but replicate splits of 36 grab samples were analyzed for sediment texture. The number of splits was not constant but ranged from 1 to 8 per grab. Replicate analyses of mineral composition were too few for a statistical evaluation, as emphasis 
TABLE 1.-Analysis of variance table for texture variables [SS - sum of squares; df - degrees of freedom; MS - mean square]

\begin{tabular}{|c|c|c|c|c|c|c|}
\hline Variable & sv & SS & df & MS & F & $\begin{array}{l}\text { Minimum resolvable } \\
\text { difference }\end{array}$ \\
\hline Percent gravel & Grabs & $\begin{array}{r}58823.55 \\
5569.23\end{array}$ & 35 & 1680.67 & 28.972 & 9.9 percent \\
\hline \multirow[t]{2}{*}{ Percent sand } & Grabs & 88766.50 & $\begin{array}{l}90 \\
35\end{array}$ & $\begin{array}{r}58.01 \\
2536.19\end{array}$ & 28.117 & 12.4 percent \\
\hline & Splits & 8659.49 & 96 & 90.20 & & \\
\hline Percent silt & Grabs & 46185.56 & 35 & 1319.59 & 25.698 & 9.3 percent \\
\hline \multirow[t]{2}{*}{ Percent clay } & $\begin{array}{l}\text { Splits } \\
\text { Grabs }\end{array}$ & $\begin{array}{l}4929.36 \\
1836.20\end{array}$ & $\begin{array}{l}96 \\
35\end{array}$ & $\begin{array}{l}51.35 \\
52.46\end{array}$ & 5.888 & 3.9 percent \\
\hline & $\begin{array}{l}\text { Splits } \\
\text { Grabs }\end{array}$ & $\begin{array}{l}855.45 \\
388.14\end{array}$ & $\begin{array}{l}96 \\
35\end{array}$ & $\begin{array}{r}8.91 \\
11.09\end{array}$ & 23.596 & $.89 \phi$ unit \\
\hline Median & Splits & 44.83 & 96 & .47 & & \\
\hline \multirow[t]{2}{*}{ Mean } & Grabs & 377.98 & 35 & 10.79 & 19.618 & $.97 \phi$ unit \\
\hline & Splits & $\begin{array}{r}52.98 \\
10915\end{array}$ & 96 & $\begin{array}{r}.55 \\
312\end{array}$ & & \\
\hline Standard deviation & $\begin{array}{l}\text { Grabs } \\
\text { Splits }\end{array}$ & $\begin{array}{r}109.15 \\
22.39\end{array}$ & $\begin{array}{l}35 \\
96\end{array}$ & $\begin{array}{r}3.12 \\
.23\end{array}$ & 13.565 & .63 \\
\hline \multirow[t]{2}{*}{ Skewness ... } & Grabs & 8.65 & 35 & .25 & 3.571 & .35 \\
\hline & Splits & 6.24 & 96 & .07 & & \\
\hline \multirow[t]{2}{*}{ Kurtosis } & Grabs & 201.77 & 35 & 5.76 & 3.064 & 1.79 \\
\hline & Splits & 180.24 & 96 & 1.88 & & \\
\hline \multirow[t]{2}{*}{ Mode ........... } & Grabs & 789.92 & 35 & 22.57 & 38.254 & $1.00 \phi$ unit \\
\hline & Splits & 56.20 & 96 & .59 & & \\
\hline
\end{tabular}

was placed upon a reconnaissance coverage of the study area.

A one-way analysis of variance based upon the random-effects model was used to provide the results on sediment texture (table 1). There was no data transformation. The F-ratios compare the variability between grab samples (and since only one grab sample was taken at a station, this variability can be thought of as between-station variability) with the variability between splits of the grab sample. For all variables, the F-ratio is significant with greater than 95 percent confidence; this means that there is greater variability between grab samples ("stations") than within them. Had this not been the case, further discussion of geographic distribution of the variables would have been statistically meaningless.

The different values of the F-ratio indicate that some variables are more diagnostic of differences between grab samples than others (Kelley and McManus, 1969; 1970). The modal size and percents gravel, sand, and silt show the most recognizable between-grab differences; percent clay, skewness, and kurtosis are less efficient. As a measure of the degree to which the variables are sensitive to betweengrab differences, the minimum resolvable difference between means of grab samples can be computed by using a measure based upon the power of the F-test (McIntyre, 1963; Kelley and McManus, 1969; 1970). Because the number of splits was not constant, $n_{S}$ in the equation of Kelley and McManus (1969) has been approximated by $n_{O}$ according to the method of Snedecor (1956, p. 269). The minimum resolvable difference for each variable, presented in table 1 , should be used only in a broad sense, as representing minimum significant contour intervals, not to compare specific values of two adjacent stations for significance in relation to a common population.

\section{DISTRIBUTION OF SEDIMENTS}

GRAVEL

Gravel and gravel-rich sediments occur (1) in Bering, Anadyr, and Shpanberg Straits, (2) in a belt approximately $30 \mathrm{~km}$ wide along most of the coast from east of Nome to the Bering Strait, (3) in the northern part of the Chukotka Trough, (4) in a belt about $10 \mathrm{~km}$ wide along the north coast of St. Lawrence Island, and (5) in a narrow belt that extends some $60 \mathrm{~km}$ northward from St. Lawrence Island along the eastern boundary of Gambell Shoal (figs. 4 and 5). Although ice-rafting may play a role in the distribution of pebbly muds, the gravel deposits observed in detailed studies near Nome are relict or residual and are derived from glacial drift, outwash, alluvium, and bedrock distributed in a complex pattern in the nearshore area (Nelson and Hopkins, 1972). The coarse deposits near Nome form an irregular belt parallel to shore seaward from the modern nearshore sand body; the coarse deposits extend seaward in lobes reflecting offshore distribution of glacial drift and bedrock outcrops. This same model of complex gravel distribution probably obtains for all the gravel regions of northern Bering Sea. The lithology of the submerged gravel in the central and eastern part of the study area is closely related to the lithology of adjacent coastal areas, whereas the gravel of the western part consists largely of exotic material. 
Basaltic volcanic rocks from nearby Quaternary eruptive centers predominate in the nearshore zone off the mountains of central St. Lawrence Island

(fig. 4). Gravel off the east coast of St. Lawrence Island consists predominantly of granite, limestone, and sedimentary rocks of local derivation. Along the

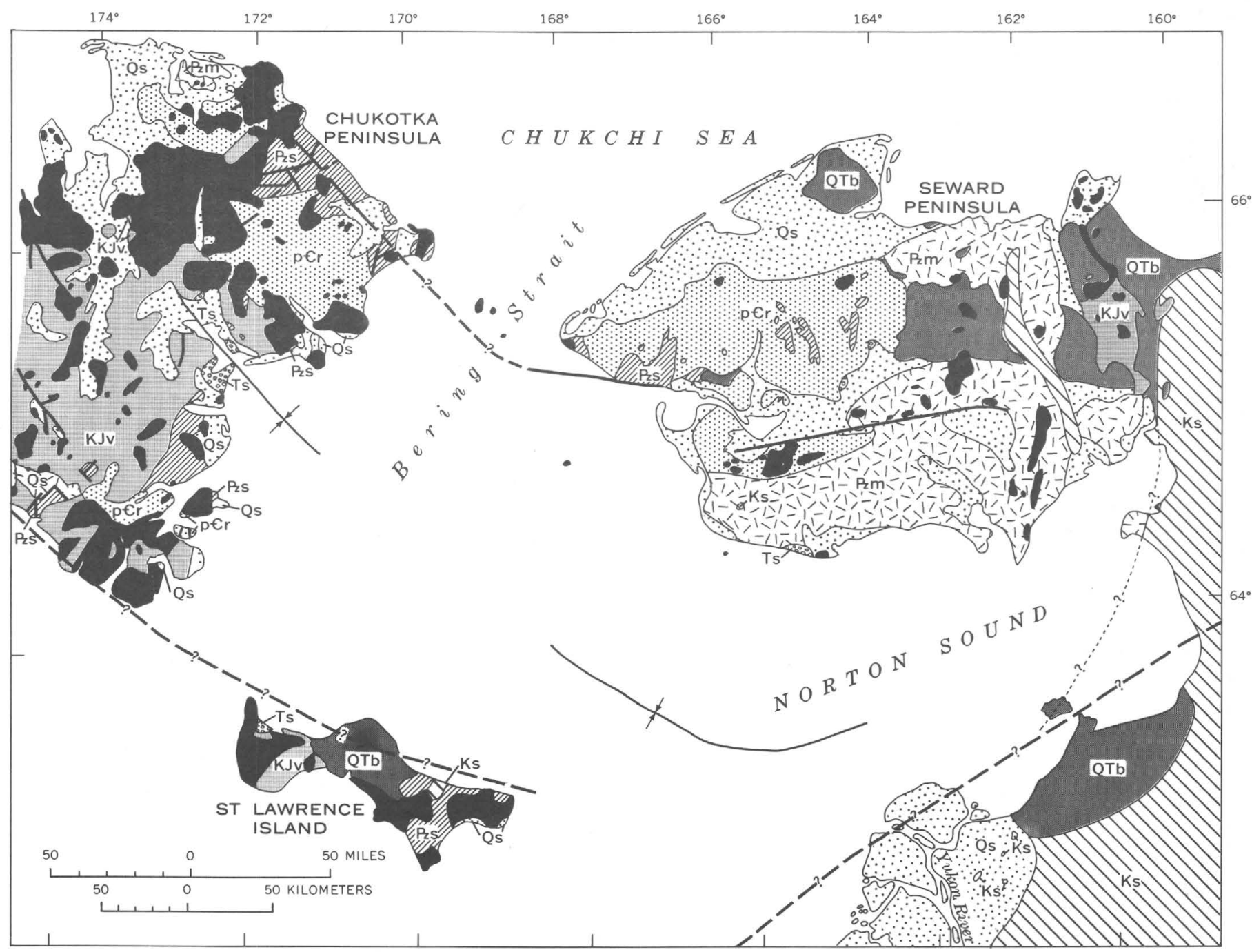

EXPLANATION

\section{$\because \because \mathrm{Q}: \because$}

Sediments

Alluvium, glacial drift, windblown silt, and marine deposits

\section{$\because \because 30: 0$}

Sedimentary rocks Includes some volcanic tuffs on St. Lawrence Island

AKs

Sedimentary rocks

$$
\mathrm{KJV}
$$

Volcanic rocks

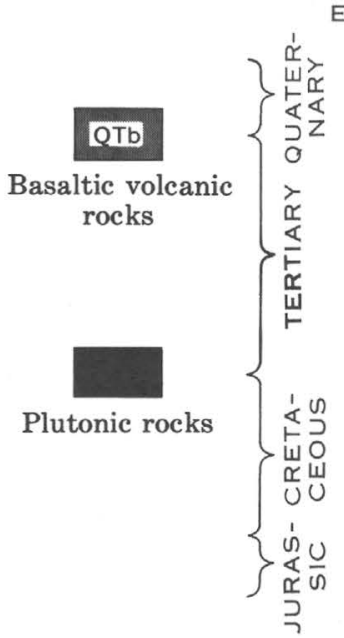

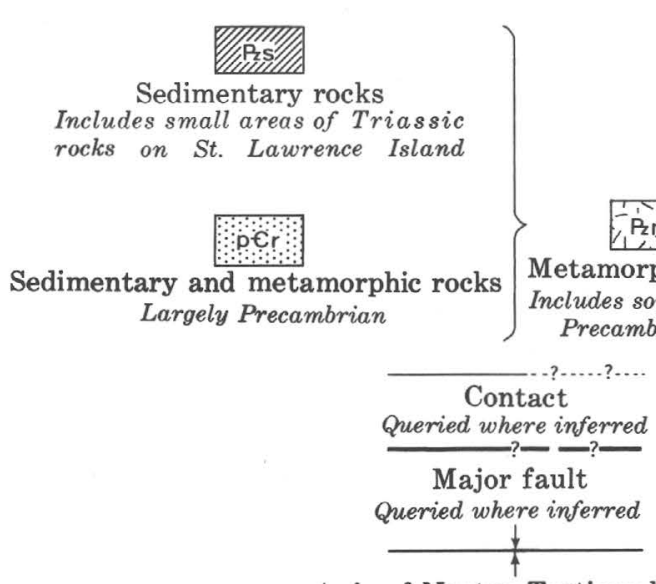

Axis of Norton Tertiary basin

FiguRE 4.-Generalized geologic map of land areas around northern Bering Sea (Nelson and Hopkins, 1972). 


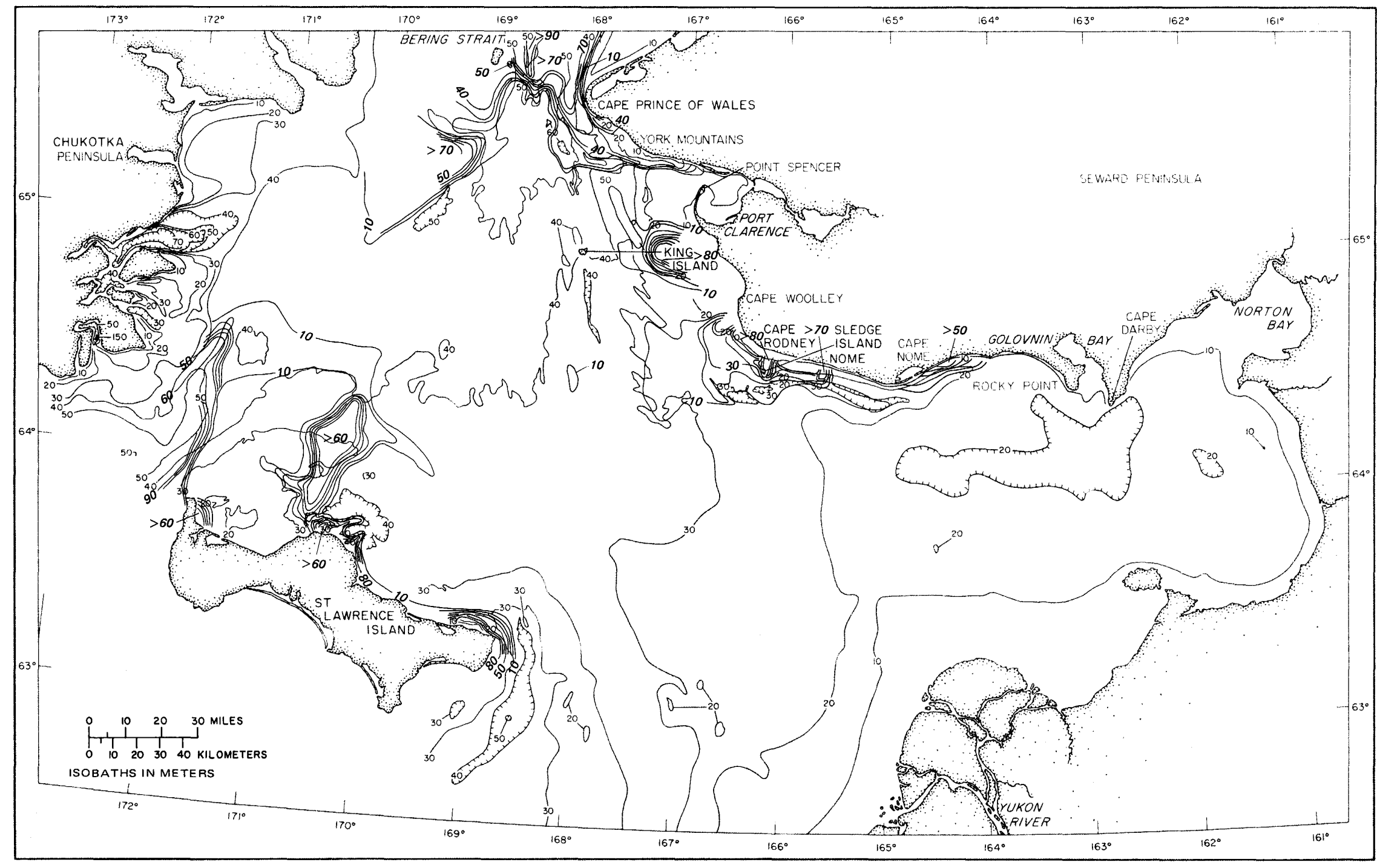

FIGURE 5.-Distribution of weight percent gravel in bottom sediments. Contour interval 10 percent. "More than" values are shown in nearshore areas where gravel content is high and increasing shoreward. 
Seward Peninsula coast from Solomon to Port Clarence, offshore gravel is predominantly quartzite, quartz-mica schist, garnet-hornblende schist, marble, lime-silicate rocks, and vein quartz derived from the local low-grade metamorphic terrane. Between Cape Nome and Cape Wooley, the gravel consists of granitic rocks and high-grade metamorphic rocks derived from mountains a few tens of miles inland and from two coastal plutons.

A very different suite of rock types is found in gravel along the Seward Peninsula coast westward from Port Clarence, near King Island, in Bering Strait, in Anadyr Strait, along the coast of western St. Lawrence Island, and in the finger of gravel extending northward from central St. Lawrence Island. Volcanic rocks of acid and intermediate composition (dacite, rhyodacite, quartz latite, and andesite) and plutonic rocks of varied composition ranging from granite to gabbro are prominent and commonly predominate in gravel samples from these areas. Acid and intermediate volcanic rocks are not present in the bedrock of western Seward Peninsula and the smaller islands of Bering Sea, but are widely distributed in the Chukotka Peninsula and on western St. Lawrence Island. There is abundant evidence to indicate that the gravel of the western part of the Bering Sea consists largely of relict morainal material derived from the Chukotka Peninsula (Hopkins and others, 1969; Silberman, 1969; Grim and McManus, 1970; Hopkins and others, 1972; Nelson and Hopkins, 1972). Our detailed studies, however, indicate that slate and limestone from the York Mountains mixed with volcanic rocks from Chukotka are a major constituent in the nearshore gravel between Port Clarence and Bering Strait. Unpublished studies by Hopkins indicate that clasts eroded from submerged outcrops of serpentinite and gabbro are mixed with the glacially transported relict gravel in some areas near St. Lawrence Island.

In the region north and west of western St. Lawrence Island, copper sulfide mineral grains of presumed Chukotka origin are present in some pebbles of altered andesite and diabase. Native copper has been found in the sand-sized component of samples from this region.

\section{SILT}

The distribution of the mud (silt plus clay) component leads to insights that help us understand the sand distribution. Therefore, we shall discuss the distribution of silt and clay before discussing the pattern of sand distribution.

The highest silt percentages are associated with the Yukon River and with some depressions in the sea floor (fig. 6). The area of high silt abundance extends northward, down current from the delta, apparently in fingerlike projections. Although the axial shoal and depression in Norton Sound have a low silt content, the depression along the northern margin of the shoal contains silt in nearly the same proportion as found near the Yukon mouth. Silt dominates sediments in this depression farther east, near Nome, but only on the south side, rather than in the depression proper. A tongue of sediment containing more than 10 percent silt extends northwestward from Sledge Island toward King Island, but little silt is present in the bottom sediments on either side. This northwest-trending tongue of silty sediment is independent of the topography. Northwest-trending ridges and troughs are present both in the area of silty sediment and in areas to either side where the silt content is less than 10 percent.

In Shpanberg Strait the silt content decreases rapidly westward from the Yukon Delta to a point about $75 \mathrm{~km}$ offshore, where it stabilizes at $10-20$ percent. Bottom sediments on the shoals have a silt content of less than 10 percent, but silt constitutes more than 30 percent of the sediment in the easternmost depression in Shpanberg Strait. A relatively high silt content characterizes the sediments in the depression along the north coast of eastern St. Lawrence Island.

The northern part of the Chukotka Trough is characterized by a slightly higher silt content. This mainly is the smoother and flatter floored part of the trough, although the closed depression just south of Bering Strait is also included. A high silt content marks the western flank of Prince of Wales Shoal; this silt extends northward from Cape Prince of Wales into the Chukchi Sea.

\section{CLAY}

The distribution of clay-sized particles (fig. 7) is contoured at the minimum resolvable difference, 4 percent. The low F-ratio indicates that this variable is not so diagnostic of differences between grab samples (stations) as the silt, which, however, has a similar pattern. Presumably, the lesser effectiveness of the clay percent in distinguishing between grab samples is associated with the generally low percentage of this size particle in most of the samples.

In an analysis of the clay mineralogy of 24 selected samples from the study area, Moll (1970) concluded that there were two clay mineral assemblages. The western assemblage (west of the dashed line in fig. 7), considered to be the Chirikov Basin assemblage, contains a larger amount of collapsible components and lower values of illite and chlorite. Clay minerals 


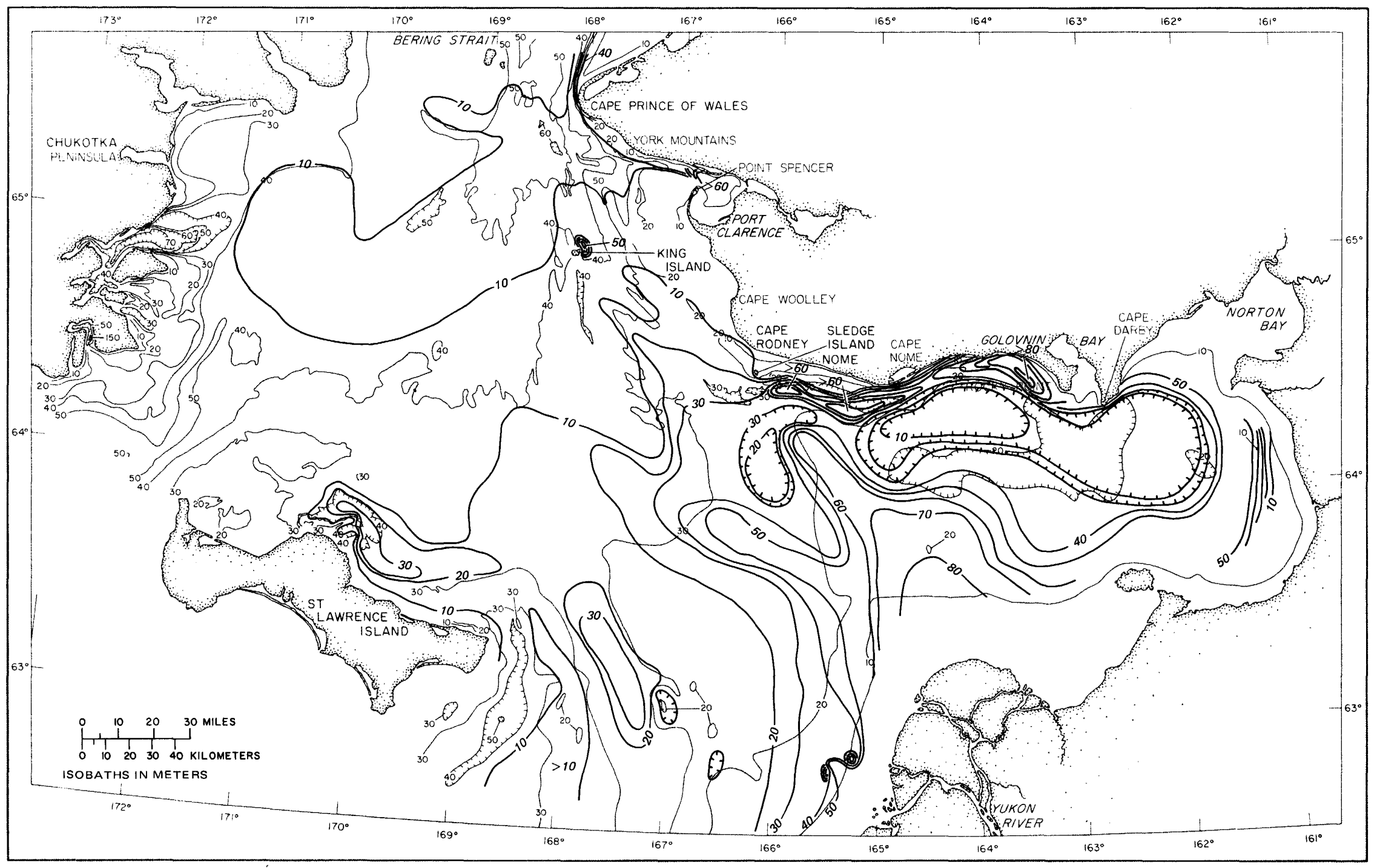

FIGURE 6.-Distribution of weight percent silt in bottom sediments. Contour interval 10 percent, approximately the minimum resolvable difference (9.3 percent). The patchiness is statistically significant. 


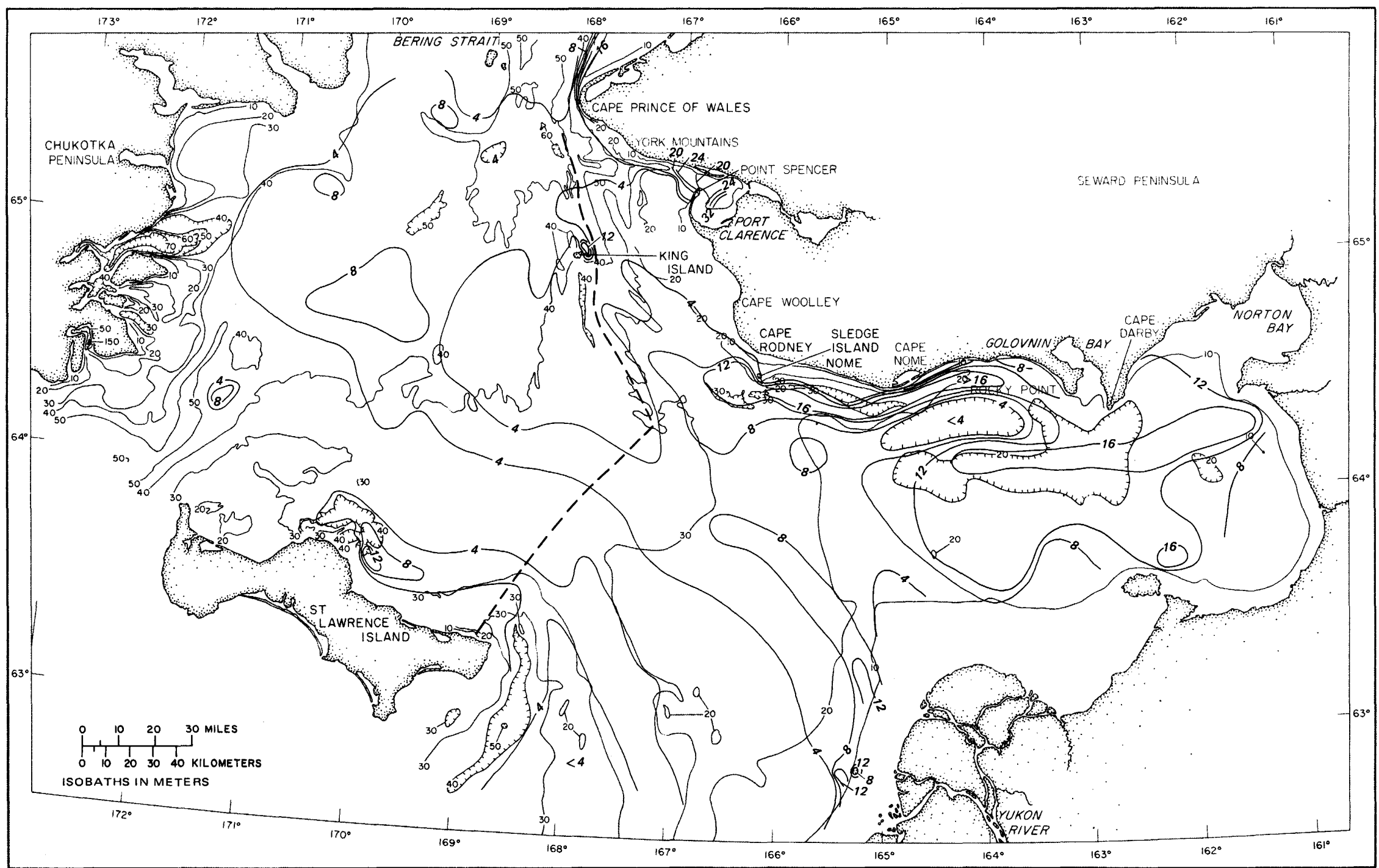

FIGURE 7.-Distribution of weight percent clay in bottom sediments. Contour interval 4 percent. The dashed line separates two clay-mineral assemblages. The western assemblage is considered to be the Chirikov Basin assemblage; the eastern assemblage the Yukon River assemblage. 


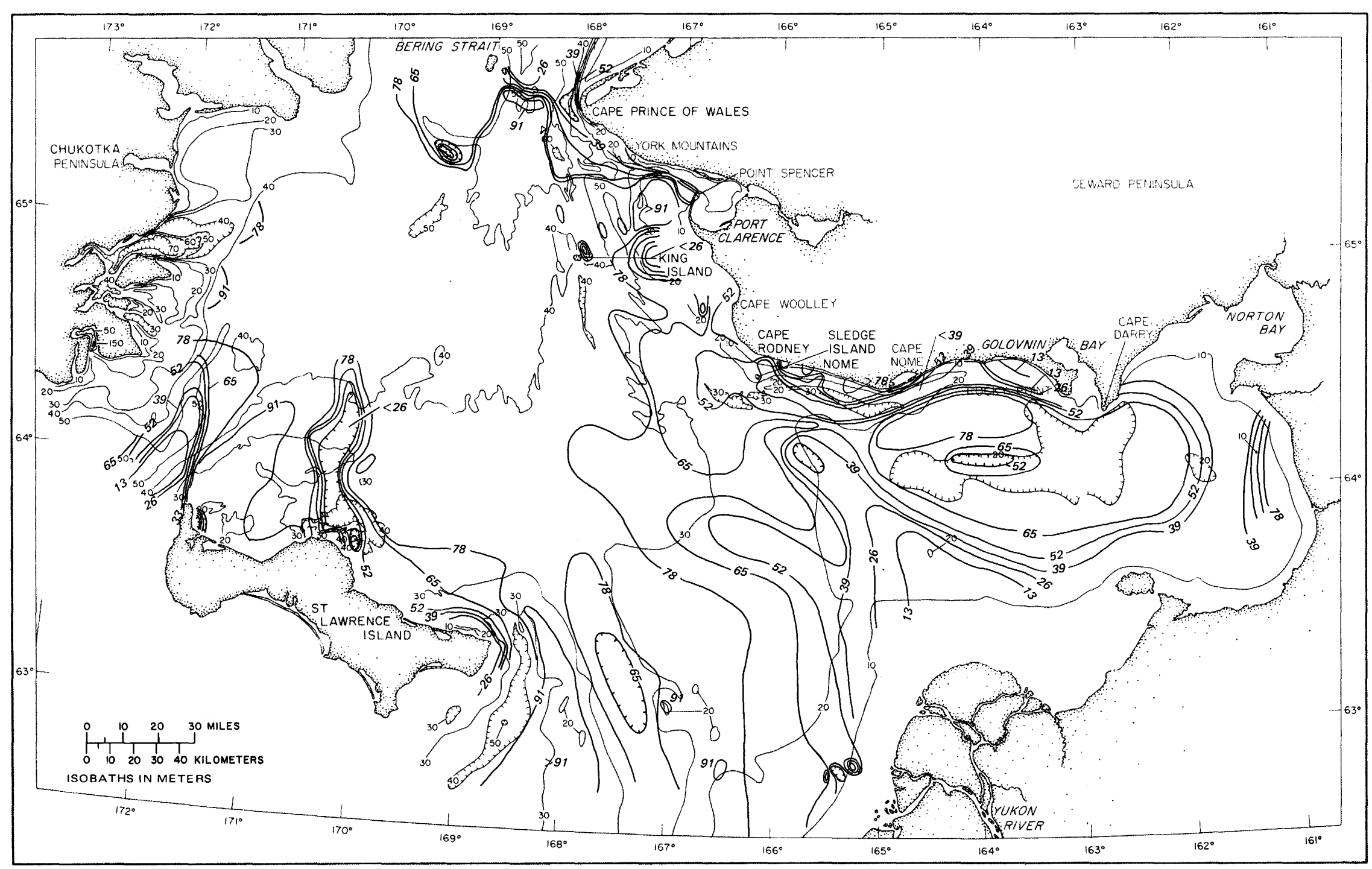

Figure 8.-Distribution of weight percent sand in bottom sediments. Contour interval 13 percent. 
of the eastern assemblage (east of this line) have an inverse ratio and appear to be associated with the present-day Yukon River sediment.

SAND

TEXTURE

The distribution pattern of percent sand (fig. 8) is merely the complement of the sum of the other distributions because of the closed-number system. The pattern does, however, more clearly indicate the high sand content of the shoals at the western tip of St. Lawrence Island, in Port Clarence, in Shpanberg Strait (particularly the western shoal), and in Norton Sound. Variation within the uniformly sandy Chirikov Basin is not depicted, as the use of a smaller contour interval would produce unreliable results. Instead, the distribution of the modal class is used (fig. 9).

The large F-ratio for the mode indicates that this variable is very diagnostic in differentiating between grabs (stations), but it should be noted that the class interval used in figure 9 is one-half the minimum resolvable difference (table 1 ). The pattern shown is therefore statistically questionable, though geologically reasonable.

One of the sedimentary characteristics illustrated by a distribution of modal sizes is grading, commonly presented as a function of water depth or distance from shore. In the present study area, there are two prominent examples of size grading. In the eastern part of Shpanberg Strait, grading is from 2.5$3.0 \phi$ sand to the finer-than $-4 \phi$ material that covers most of Norton Sound. The 3.0-3.5 $\phi$ and 3.5-4.0 $\phi$ sands seem to be closely associated with the silt distribution pattern and to form a pattern distinctly different from that of the 2.5-3.0 $\phi$ mode that dominates Shpanberg Strait.

The second example of size grading begins with the medium sand (1.5-2.0 $\phi)$ in the nearshore part of the Cape Rodney Parallel Valley Area. Seaward, the mode is 2.0-2.5 $\phi$ down the eastern flank of the Chirikov Ramp area. It is 2.5-3.0 $\phi$ throughout the rest of this province and becomes $3.0-3.5 \phi$ in the Chukotka Trough to the west and in the southern part of the Norton Plain. In the center of the Chukotka Trough and near eastern St. Lawrence Island, the mode is 3.5-4.0 $\phi$. This size grading extends to the secondary mode in each of these modal zones. The secondary mode in the coarser grained zone is the same as the primary mode in the adjacent finer grained zone. As comparison with the bathymetric chart shows (fig. 2 ), however, this size grading cannot be related directly to either water depth or distance from shore.
Most of the bottom sediments in the study area are poorly to very poorly sorted (fig. 10). The very poorly sorted sediments are gravels or silts. The best sorting is found in the sands near the Yukon, off some beaches, and at two depths on various shoals, $34 \mathrm{~m}$ and $20 \mathrm{~m}$, the shallower depth being the crest of some shoals.

\section{LIGHT MINERALS}

Thirty-six samples were analyzed for light minerals in the 2.75-4.00 $\phi$ class. Quartz forms more than 50 percent of the fraction in samples from the eastwest shoal in Norton Sound and in the northern half of the Chirikov Basin. Elsewhere feldspar is the major component. A plot of the ratio of plagioclase to $\mathrm{K}$-feldspar (fig. 11) shows a dominance of plagioclase near the Yukon River, including most of Norton Sound and Shpanberg Strait, and near the basalts of central St. Lawrence Island. K-feldspar predominates in samples from off the east and west ends of the island and is the dominant feldspar in most of the Chirikov Basin. In northeastern Norton Sound, the K-feldspar content is high but not dominant.

\section{HEAVY MINERALS}

The heavy-mineral content of the total 1-4 $\phi$ sand class, disregarding beach samples, rarely exceeds 10 percent, although a maximum of 78 percent was recorded. For the fine sands (2.75-4.00 $\phi$ class), which include the most common modal sizes, heavymineral contents exceeding 16 percent are observed in brownish sand at depths of 34-36 m west of St. Lawrence Island, adjacent to the volcanic rocks of the central part of the island, on the shoal crests $(20$ m) in Shpanberg Strait, along the Nome coast, and in the Cape Rodney Parallel Valley Area and the Point Spencer Shoal Area (Venkatarathnam, 1971).

Venkatarathnam (1971) lists the heavy-mineral assemblages and delimits a number of heavymineral provinces on the basis of the total sand (1-4 $\phi)$ fraction. In an attempt to better define the relations among provinces, 100 samples of the 2.75$4.00 \phi$ fraction were subjected to a $Q$-mode factor analysis following the procedure of Imbrie and van Andel (1964), with the constraint that the mineral data (percentages) were transformed into percent of range, even though, as Imbrie and van Andel (1964, p. 1144) point out, "the proportionally large standard error of small percentages produces very noisy data." Consequently, our use of the percent range transformation is open to question; on the other hand, ignoring the minerals present in small percentages could mean ignoring some very important minerals (Blatt, 1967). 


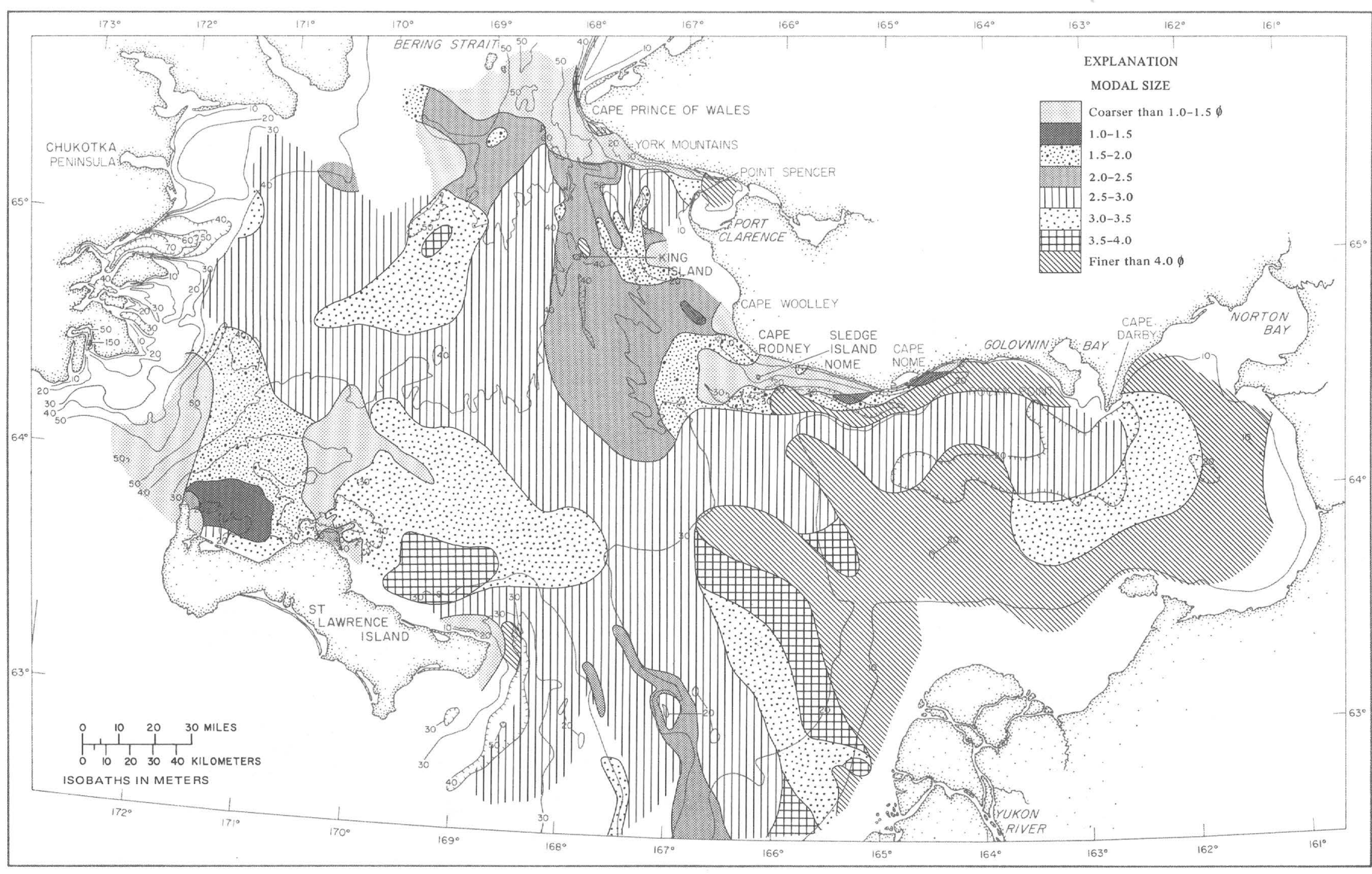

曷

Figure 9.-Distribution of modal classes of sand. The class interval is less than the minimum resolvable difference. 


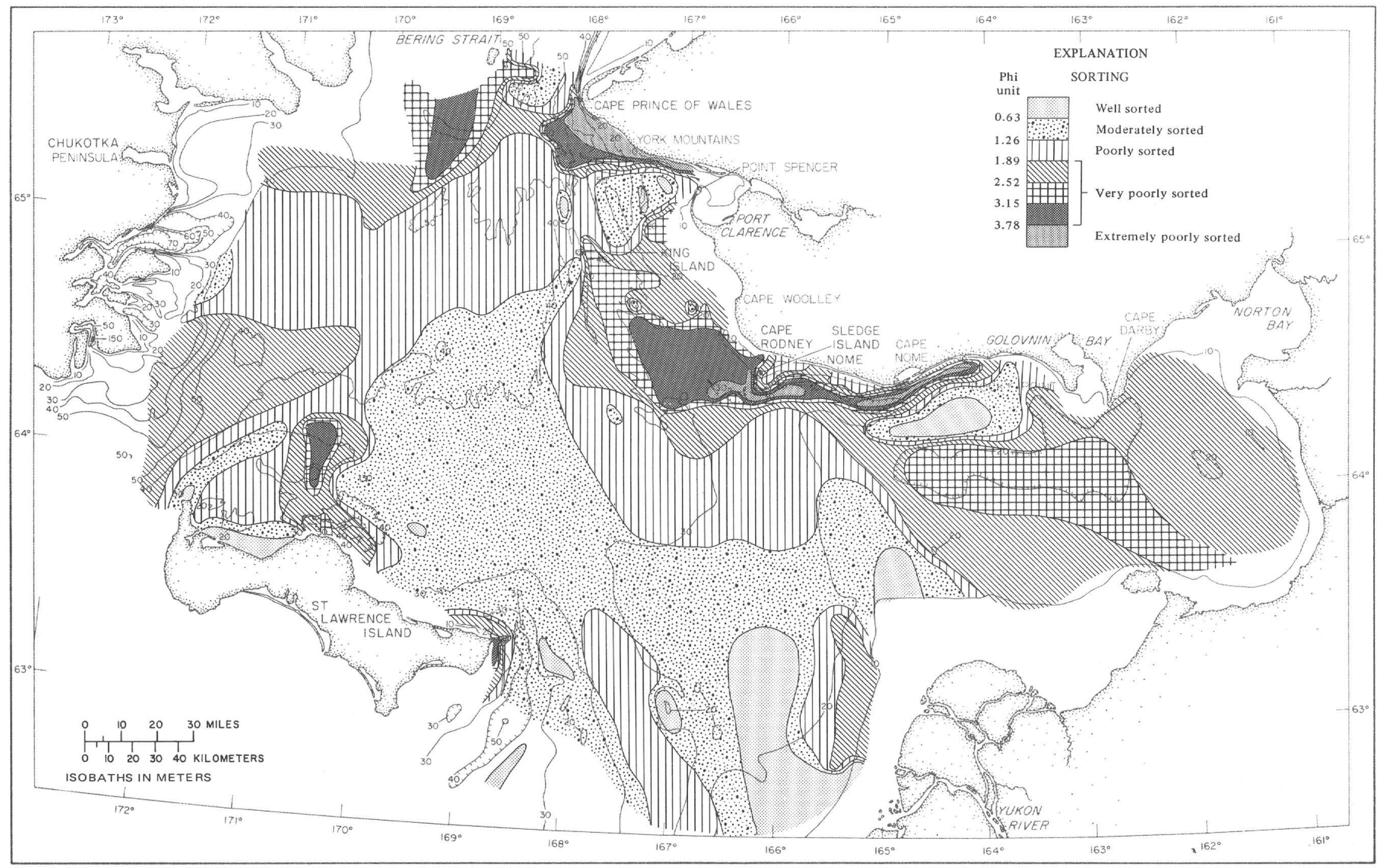




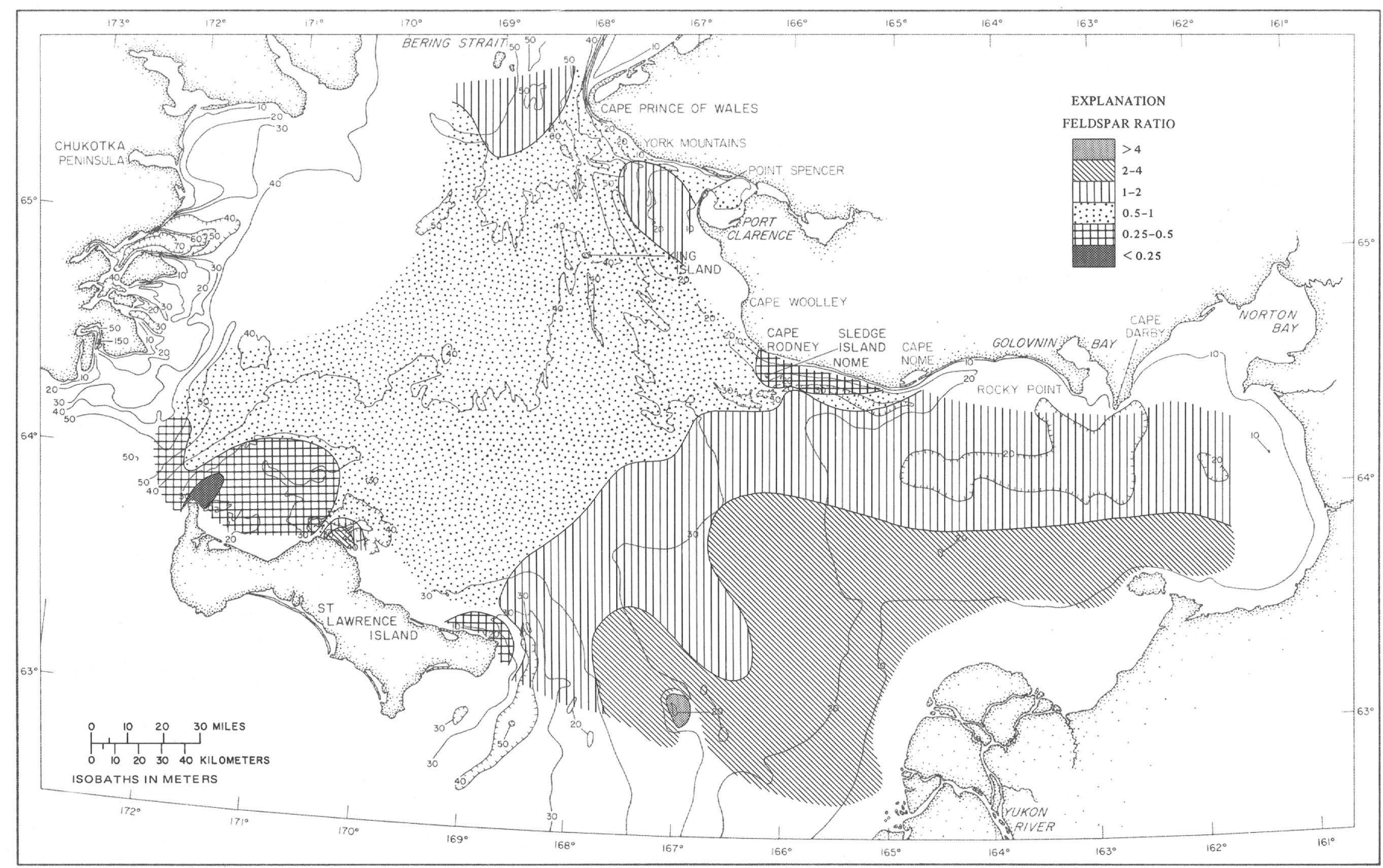

Figure 11.-Ratio of plagioclase to K-feldspar in the $2.75-4.00 \phi$ class. 
TABLE 2.-Values of 13 variables for samples of four highest loadings for each factor in Q-mode analysis of heavy-mineral composition

\begin{tabular}{|c|c|c|c|c|c|c|c|c|c|c|c|c|c|c|c|}
\hline Factor & Sample & 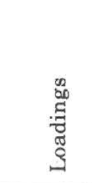 & 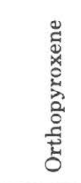 & 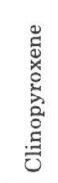 & 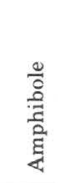 & 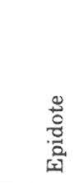 & 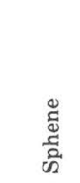 & 苋 & 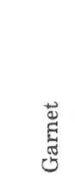 & 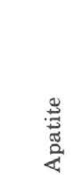 & 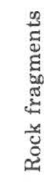 & 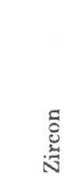 & 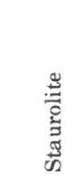 & 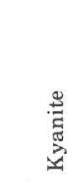 & 总 \\
\hline I & $\begin{array}{l}\text { TT018-23 } \\
\text { TT018-22 } \\
\text { 69ANC-116 } \\
\text { 69ANC-111 }\end{array}$ & $\begin{array}{r}1.000 \\
.998 \\
.919 \\
.910\end{array}$ & $\begin{array}{l}16 \\
18 \\
15 \\
12\end{array}$ & $\begin{array}{l}32 \\
32 \\
32 \\
34\end{array}$ & $\begin{array}{r}5 \\
10 \\
5 \\
16\end{array}$ & $\begin{array}{r}7 \\
6 \\
14 \\
9\end{array}$ & $\begin{array}{l}1 \\
2 \\
1 \\
2\end{array}$ & $\begin{array}{l}1 \\
2 \\
1 \\
2\end{array}$ & $\begin{array}{r}15 \\
9 \\
4 \\
4\end{array}$ & $\begin{array}{c}<\overline{0.5} \\
1 \\
<0.5\end{array}$ & $\begin{array}{l}21 \\
20 \\
17 \\
20\end{array}$ & $\begin{array}{l}1 \\
- \\
-\end{array}$ & $\begin{aligned} & 2 \\
< & 0.5 \\
< & 0.5 \\
< & 0.5\end{aligned}$ & $\begin{aligned}<\overline{0.5} \\
- \\
-\end{aligned}$ & $\frac{1}{-}$ \\
\hline II & $\begin{array}{l}\text { GR493-A } \\
\text { VC067-116 } \\
\text { VC067-99 } \\
\text { VC067-67 }\end{array}$ & $\begin{array}{r}1.000 \\
.957 \\
.947 \\
.936\end{array}$ & $\begin{array}{c}-\overline{0.5} \\
1 \\
1\end{array}$ & $\begin{array}{l}4 \\
3 \\
4 \\
4\end{array}$ & $\begin{array}{l}3 \\
6 \\
5 \\
7\end{array}$ & $\begin{array}{r}9 \\
13 \\
24 \\
16\end{array}$ & $\begin{array}{l}5 \\
4 \\
4 \\
6\end{array}$ & $\begin{array}{l}1 \\
- \\
-\end{array}$ & $\begin{array}{l}60 \\
62 \\
51 \\
51\end{array}$ & $\begin{array}{l}1 \\
1 \\
1 \\
1\end{array}$ & $\begin{array}{l}8 \\
4 \\
5 \\
8\end{array}$ & $\begin{array}{l}- \\
- \\
-\end{array}$ & $\begin{array}{l}4 \\
2 \\
1 \\
2\end{array}$ & $\begin{array}{c}<0.5 \\
- \\
-\end{array}$ & $\begin{array}{l}5 \\
4 \\
5 \\
4\end{array}$ \\
\hline III & $\begin{array}{l}\text { 68ANC-116 } \\
69 \text { ANC-97 } \\
69 \text { ANC-88 } \\
68 \text { ANC-102B }\end{array}$ & $\begin{array}{r}1.000 \\
.970 \\
.959 \\
.642\end{array}$ & $\frac{-}{-}$ & $\begin{array}{r}21 \\
11 \\
6 \\
35\end{array}$ & $\begin{array}{l}3 \\
1 \\
1 \\
4\end{array}$ & $\begin{array}{c}1 \\
2 \\
<0.5 \\
10\end{array}$ & $\begin{array}{c}1 \\
<0.5 \\
1 \\
1\end{array}$ & $\begin{array}{l}71 \\
82 \\
90 \\
36\end{array}$ & $\begin{array}{c}\frac{1}{<0.5} \\
1\end{array}$ & $\begin{array}{l}- \\
- \\
-\end{array}$ & $\begin{array}{r}2 \\
4 \\
1 \\
11\end{array}$ & $\begin{array}{c}<0.5 \\
- \\
-\end{array}$ & $\begin{array}{c}\overline{-} \\
\overline{<0.5}\end{array}$ & $\begin{array}{l}- \\
- \\
-\end{array}$ & $\begin{array}{l}- \\
- \\
-\end{array}$ \\
\hline IV & $\begin{array}{l}\text { TT018-10 } \\
\text { TT018-40 } \\
\text { 68ANC-84 } \\
\text { 68ANC-156 }\end{array}$ & $\begin{array}{r}1.000 \\
.957 \\
.875 \\
.859\end{array}$ & $\begin{array}{l}1 \\
7 \\
3 \\
9\end{array}$ & $\begin{array}{l}45 \\
45 \\
23 \\
38\end{array}$ & $\begin{array}{r}29 \\
20 \\
32 \\
6\end{array}$ & $\begin{array}{r}2 \\
6 \\
11 \\
15\end{array}$ & $\begin{array}{l}7 \\
2 \\
5 \\
3\end{array}$ & $\begin{array}{c}<0.5 \\
2 \\
<0.5 \\
1\end{array}$ & $\begin{array}{r}6 \\
4 \\
11 \\
8\end{array}$ & $\begin{array}{l}1 \\
2 \\
2 \\
3\end{array}$ & $\begin{array}{r}4 \\
7 \\
11 \\
11\end{array}$ & $\begin{array}{l}- \\
- \\
-\end{array}$ & $\begin{array}{c}- \\
- \\
<0.5\end{array}$ & $\begin{array}{l}<0.5 \\
<0.5 \\
<0.5 \\
\quad 1\end{array}$ & $\begin{array}{l}5 \\
1 \\
1 \\
3\end{array}$ \\
\hline
\end{tabular}

A Q-mode analysis was run, using 13 nonopaque minerals for each of the 100 samples. Four factors "explained" 90 percent of the variability displayed by the samples (table 2). The fifth eigenvalue constituted only 2 percent of the trace. These factors are considered to indicate sediment provenance, although the mineralogy of the rocks on the adjacent land is poorly known. The mineral assemblages do not appear to have been altered by selective removal of unstable grains due to weathering. In fact, the heavy mineral grains show little evidence of weathering; this holds true even for the most easily weathered species, such as olivine. Size sorting of minerals may have had some effect upon the assemblages. We note, for example, an increase in amphibole and pyroxene and a decrease in garnet in the 2.75-4.00 $\phi$ class with decreasing median size of the total sand fraction. However, comparison of abundances in the 1.0-2.75 $\mathrm{o}$ and 2.75-4.00 $\phi$ classes suggests that size sorting is not a dominant effect, as the mineral composition of the two classes is essentially the same in a given sample (Venkatarathnam, 1971). Variations in the mineralogy of the source rocks that supplied detritus to the study area appear to control the heavy-mineral variation in the bottom sediments.

Factor I is thought to represent Yukon River sand. Its distribution (fig. 12A) shows high values near the Yukon Delta, and there is a similarity between the distributions of high Factor I loadings in Norton Sound and the $5 \phi$ mode of Yukon silt. The dominant components of the factor are clinopyroxenes, rock fragments, orthopyroxenes, and amphiboles (table 2 ). At this stage in the discussion of the heavymineral factors, there is no implication of geologic time, only of provenance. Whether or not the areas of high loadings of this and other factors are now receiving sediments of the inferred provenance will be discussed later.

Although Factor II is expressed most strongly by garnet, and thus might appear to be monomineralic (table 2), comparison with the other factors suggests that the epidote, staurolite, chloritoid, and sphene are significant. Accordingly, the factor appears to be formed of metamorphic minerals, and the distribution (fig. 12B) indicates the source area to be the metamorphic rocks of southwestern Seward Peninsula. The factor is mainly developed within and inshore from the depression along the coast near Nome and in the Cape Rodney Parallel Valley Area just to the west. The role of this and other factors amid the Point Spencer Shoal Area requires detailed study.

Factor III consists of olivine and clinopyroxene derived from the Quaternary olivine basalts (table 2) and can easily be correlated with volcanic rocks in the adjoining land area (fig. 12C).

As Factor IV is the final factor, its distribution (fig. $12 D)$ may reflect a complementary element to the sum of the other factors. The multimineral composition of the factor enhances this possibility. This does not, however, appear to be the most probable interpretation.

Factor IV consists of clinopyroxene, amphibole, rock fragments, and epidote, a suite that appears to be derived from the Jurassic and Cretaceous volcanic rocks and the associated acidic plutons of the Okhotsk volcanic belt. The Okhotsk volcanic belt encompasses the southern half of Chukotka Penin- 


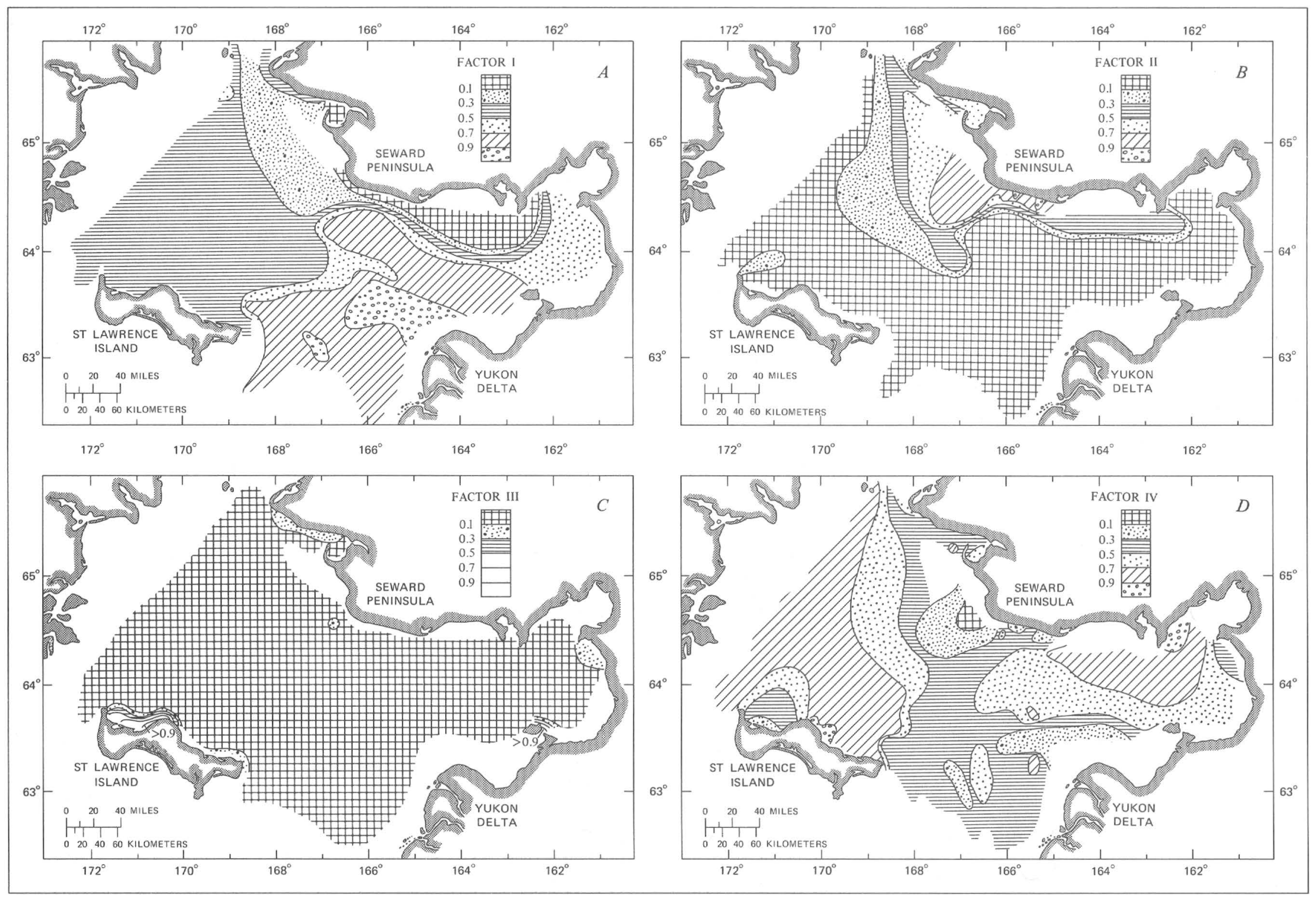

FIGURE 12.-Distribution (percent) of factors from Q-mode factor analysis of heavy minerals in the $2.75-4.00 \phi$ class. $A$, Factor I. $B$, Factor II. C, Factor III. $D$, Factor IV. 
sula and areas farther west in Siberia (Tilman and others, 1969), extends southeastward beneath Anadyr Strait and across southwestern St. Lawrence Island, thence eastward south of the central and eastern part of the island (Patton and Csejtey, 1971; Scholl and Marlow, 1970; Nelson and others, 1974). Patton (1971) suggests that east of St. Lawrence Island, the Okhotsk volcanic belt swings northeastward, passing beneath Norton Sound to connect with a north-trending volcanic complex of similar lithology and age in the hills of southeastern Seward Peninsula.

Bottom sediments with high values for Factor IV cover the bottom in the western part of Bering Strait and extend from there southward through western Chirikov Basin and the Anadyr Strait. The principal minerals of Factor IV dominate heavy-mineral assemblages in bottom samples collected south of Anadyr Strait and along the southern Chukotka coast, where the order of abundance is: rock fragments, amphibole, clinopyroxene, and epidote (Lisitsyn, 1966). The Factor IV sediments are thus distributed across the sea bottom in areas adjoining coasts where the Okhotsk volcanic belt is exposed. These sediments are derived in part from submarine outcrops, but much of the area in which they occur is underlain by the drift of glaciers that originated on Chukotka (Nelson and Hopkins, 1972; D. M. Hopkins, C. H. Nelson, and R. B. Perry, unpub. data, 1973). Factor IV is also strongly developed in bottom sediments in northeastern Norton Sound, near the late Mesozoic volcanic and plutonic rocks exposed on southeastern Seward Peninsula.

One method of better evaluating the relations among the factors is to consider only that part of each factor distribution having loading values greater than 0.5. By this criterion five main heavy-mineral provinces can be identified (fig. 13). To prevent confusion with physiographic provinces, the heavymineral provinces will be referred to as $h-m$ provinces.

The Yukon $\mathrm{h}-\mathrm{m}$ province extends from the delta across Shpanberg Strait to the depression along the end of the St. Lawrence Island. Along the northern margin of the province, the Yukon sediment is mixed with that of the adjacent provinces, particularly in
Norton Sound. Factor IV sediment can be divided into southeastern Seward Peninsula and Chukotka $\mathrm{h}-\mathrm{m}$ provinces on the basis of the plagioclase $/ \mathrm{K}$ feldspar ratio (fig. 11), which is greater than 1 in the southeastern Seward Peninsula province. The southeastern Seward Peninsula sediment occupies the shoal in Norton Sound, and very similar sediment occurs in patches in the eastern part of Shpanberg Strait.

The southwestern Seward metamorphic h-m province is confined to the area of parallel-relief topography between Nome and Bering Strait. The remainder of the Chirikov Basin is dominated by the Chukotka h-m province. Several small Quaternary olivine basalt provinces are shown in figure 13 . Scrutiny of the detailed data indicates that several other small provinces can be distinguished off each end of St. Lawrence Island and near Cape Prince of Wales (Venkatarathnam, 1971), but none of these are recorded by the factor analysis, and they are not distinguished in figure 13. Venkatarathnam (1971) notes that the sediment in an area north of easternmost St. Lawrence Island has a somewhat mixed assemblage not recorded by the factor analysis. More obvious mixtures of provinces can be noted in figure 12 , where samples have loadings $>0.5$ for more than one factor.

\section{SEDIMENT TYPES}

The data on the mineralogy of the fine sand, particularly as summarized by figure 13 , and the pebble lithology provide a basis for interpreting the provenance of the sediments studied. To interpret the sediment processes, however, requires knowledge of the sediment texture. Although the texture has been discussed in terms of gravel, silt, clay, and sand, no summary of the textural data has been presented. To provide this information, an R-mode factor analysis (Dixon, 1970) was run, using as variables the percent sediment in each $1 / 2-\phi$ or $1-\phi$ class. The two class intervals were used to emphasize the sand sizes dominating the sediment in the Chirikov Basin. The five factors are considered to be driven by those variables having a loading greater than about 0.4 (table 3). Two of the factors are simple, representing silt-clay (Factor I) and fine gravel (Factor III). The

TABLE 3. $-R$-mode factor analysis of sediment size. Factor loadings $>+0.4$

[Five factors "explained" 74 percent of the variability]

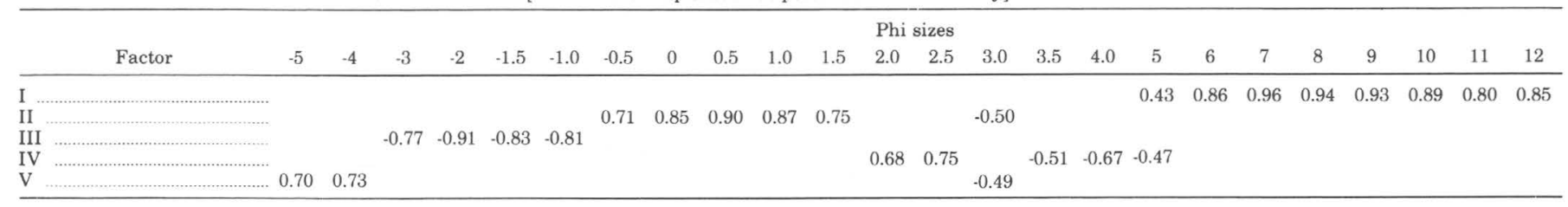




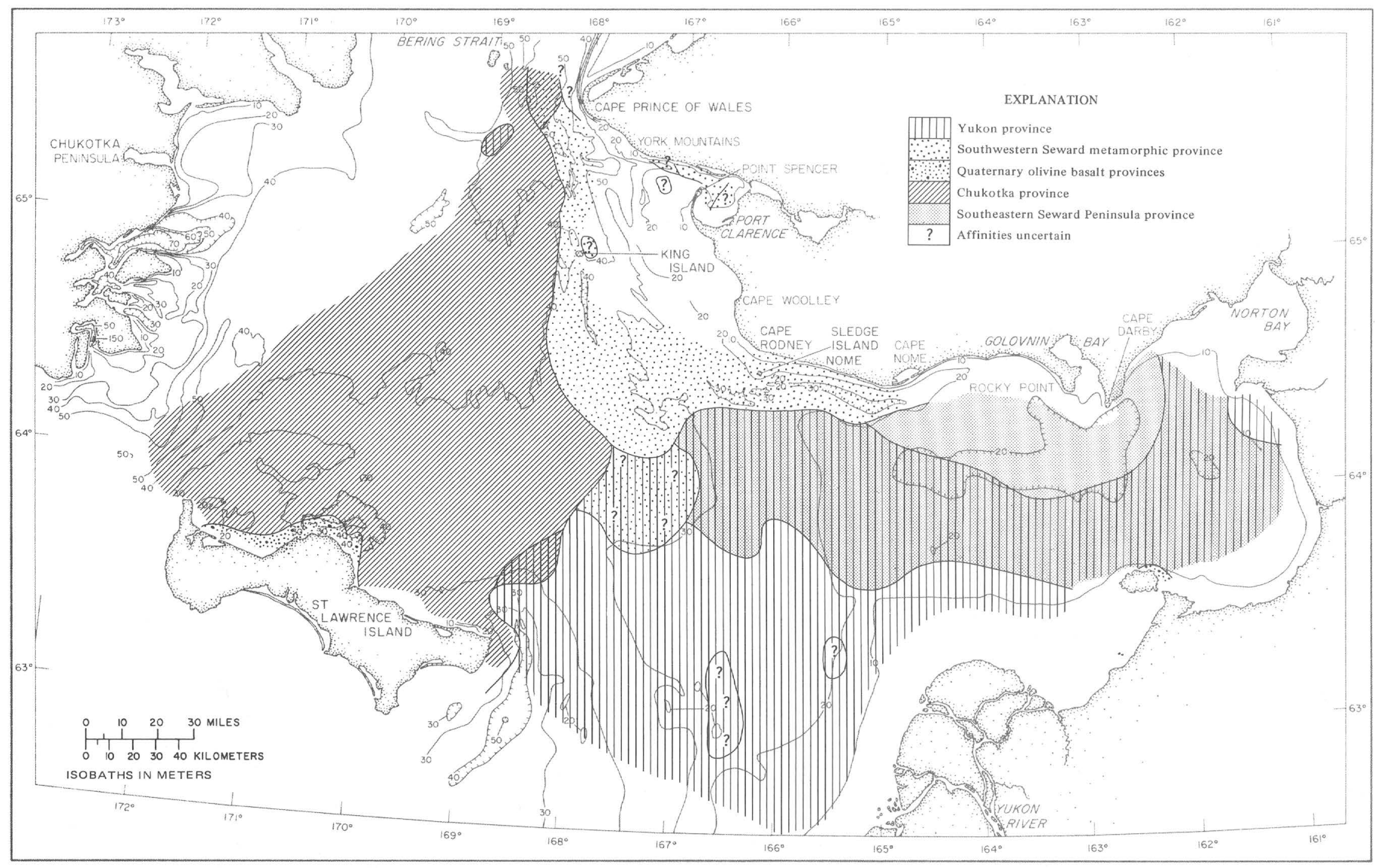

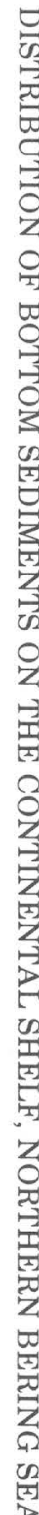
FigURE 13. - Heavy-mineral provinces determined on the basis of loading values $>0.5$ for $Q$-mode factor analysis. Several local provinces not detected by factor analysis
and not shown are defined by Venkatarathnam (1971). Note mixtures of provinces in areas where loading of $>0.5$ occurs for more than one factor. 
TABLE 4.-Values of the 24 variables for extremal samples of each factor in Q-mode factor analysis of sediment size

\begin{tabular}{|c|c|c|c|c|c|c|c|c|c|c|c|c|c|c|c|c|c|c|c|c|c|c|c|c|c|}
\hline \multirow[b]{2}{*}{ Factor } & \multirow[b]{2}{*}{ Sample No. } & \multicolumn{24}{|c|}{ Phi size } \\
\hline & & -5 & -4 & -3 & -2 & -1.5 & -1.0 & -0.5 & 0 & 0.5 & 1.0 & 1.5 & 2.0 & 2.5 & 3.0 & 3.5 & 4.0 & 5 & 6 & 7 & 8 & 9 & 10 & 11 & 12 \\
\hline \multirow{2}{*}{$I$} & 68 ANC 152 & 0 & 0 & 0 & 0 & 0 & 0 & 0.03 & 0.02 & 0.02 & 0.04 & 0.06 & 0.17 & 0.51 & 2.95 & 50.49 & 29.34 & 10.49 & 0.68 & 0.74 & 1.02 & 0.23 & 1.16 & 0.45 & 1.60 \\
\hline & $\mathrm{N}$ & 0 & 0 & 0 & 0 & 0 & 0 & .04 & .13 & 1 & .42 & .45 & .42 & .82 & 24.40 & 44.68 & 12.74 & 6.96 & 2.88 & 1.92 & .72 & 1.44 & .72 & .48 & .48 \\
\hline \multirow{3}{*}{ II ................. } & AWF 365 & 0 & 0 & 0 & 0 & .20 & 0 & .03 & .09 & .09 & .17 & .37 & .61 & 1.12 & 1.33 & 1.70 & 4.19 & 49.38 & 17.20 & 6.45 & 3.88 & 3.48 & 3.30 & 2.43 & 3.98 \\
\hline & & 0 & 0 & 0 & 0 & .81 & .35 & .11 & .35 & .27 & .43 & .36 & .25 & .13 & .68 & 4.54 & 6.37 & 35.40 & 19.83 & 9.23 & 4.23 & 3.48 & 3.93 & 3.19 & 6.06 \\
\hline & & 0 & 0 & 0 & 0 & 0 & 0 & 0 & .04 & .04 & .04 & .04 & .67 & .75 & 1.02 & 2.04 & 7.47 & 35.11 & 19.63 & 12.47 & 6.10 & 3.18 & 3.98 & 3.45 & 3.98 \\
\hline \multirow[t]{2}{*}{ III .......... } & 68 ANC 112 & 0 & 0 & 0 & 0 & .67 & .81 & 1.63 & 2.31 & 4.67 & 11.46 & 26.61 & 32.37 & 15.52 & 2.54 & .30 & .06 & .27 & .80 & 0 & 0 & 0 & 0 & 0 & 0 \\
\hline & & 0 & 0 & 0 & 0 & 0 & .37 & 8.06 & 10.15 & 12.26 & 18.78 & 15.18 & 16.04 & 9.14 & 5.91 & 2.11 & 1.56 & .37 & .06 & 0 & 0 & 0 & 0 & 0 & 0 \\
\hline \multirow[t]{3}{*}{ IV } & $68 \mathrm{Al}$ & 0 & 35.91 & 41.30 & 9.85 & 2.90 & 1.47 & .59 & .40 & .25 & .64 & 1.17 & .36 & .32 & .39 & .70 & .68 & .76 & .15 & .08 & .18 & .20 & .06 & .18 & 1.46 \\
\hline & NC 243 & 14.91 & 7.92 & 20.43 & 18.74 & 8.07 & 3.72 & 3.16 & 2.23 & 2.18 & 1.92 & 2.46 & 2.20 & 2.34 & 2.21 & .63 & .35 & 1.22 & .8 & .90 & .8 & .81 & .65 & .53 & .69 \\
\hline & & 0 & .95 & 36.50 & 27.14 & 8.08 & 4.90 & 4.79 & 3.55 & 3.37 & 2.56 & 1.70 & .94 & .41 & .96 & .56 & .36 & .86 & & .48 & .3 & .2 & .2 & .07 & .46 \\
\hline \multirow[t]{2}{*}{ V } & 69 ANC 112 & 0 & 0 & 0 & 0 & 0 & .16 & .16 & .01 & .04 & .12 & .23 & 4.92 & 23.98 & 55.21 & 8.40 & 1.75 & 2.24 & .51 & 0 & .49 & .19 & .21 & .07 & 1.30 \\
\hline & TT018-26 & 0 & 0 & 0 & 0 & 0 & 0 & 0 & 0 & 0 & 0 & .92 & 4.32 & 41.08 & 38.11 & 5.79 & 1.27 & 1.51 & .39 & .43 & .40 & .55 & .46 & .82 & 3.95 \\
\hline
\end{tabular}

other three factors are bipolar; that is, they consist of high loadings that are positive and negative. This complementary arrangement of high positive and negative loadings might be produced by geologic processes, closure of the closed-number system, or other causes. The effect of closure was evaluated, using the technique of Kelley (1971); at the 95 percent confidence level, it can be shown that the bipolarity is not due solely to closure. Consequently, it is assumed that this bipolarity is geologically significant-for example, that in Factor IV the 2.0 and $2.5 \phi$ sediments respond differently than the $3.5-4.0$, and 5 $\phi$ sediments.

To portray the areal distribution of the sediment types, a Q-mode analysis was run of the percent sediment in each class size. Five factors "explained" about 82 percent of the variability. The data for the extreme samples are shown in table 4 . The distributions plotted in figure 14 represent the sediment types in the same manner heavy-mineral factor distributions are plotted in figure 13, on the basis of loading values greater than 0.5 .

\section{DISCUSSION}

\section{PRESENT-DAY PROCESSES OF SEDIMENT TRANSPORT}

Until in situ measurements are sufficient to determine the exact nature of the processes of sediment transport, such processes can be discussed only in a highly general descriptive fashion. The only measurements of water motion directly applicable to sediment transport have been those made by R. W. Sternberg within $1 \mathrm{~m}$ of the bottom in the Modified Shelf Water of the Chirikov Basin $(4-16 \mathrm{~cm} / \mathrm{sec}$ in $34.5 \mathrm{~m}$ water depth) and in the Alaskan Coastal Water just north of Bering Strait (25-35 cm/sec in 33 m water depth) (R. W. Sternberg, written commun., 1971). Comparison of these values with current velocities measured in the water column by many workers during the ice-free season of several years (fig. 3) suggests that a velocity of $30-40 \mathrm{~cm} / \mathrm{sec}$ within a meter of the bottom might be representative of the coastal water along the Seward Peninsula coast, $5-15 \mathrm{~cm} / \mathrm{sec}$ representative of the Chirikov Basin, and $2 \mathrm{~cm} / \mathrm{sec}$ representative of the Chukotka Trough.

Assuming that $1 \mathrm{~m}$ from the bottom the Alaskan Coastal Water moves at a velocity of $30-40 \mathrm{~cm} / \mathrm{sec}$ and the Modified Shelf Water at a velocity of 5-15 $\mathrm{cm} / \mathrm{sec}$, then comparison can be made with one of various "competency curves" for sediment transport, that of Sundborg (1956). Sternberg (1971) concluded from in situ measurements that these curves adequately predicted sediment motion in some marine environments for certain size particles. Assuming that the curves are adequate for our study area, then all the modal sediment sizes underlying the coastal water except the gravel (fig. 9) should be subject to bedload transport, and some erosion would even be expected. However, little or no bedload transport of fine and medium sand would be expected beneath the Modified Shelf Water, an interpretation that is supported by the absence of bed-roughness elements in a time-series of bottom photographs made by R. W. Sternberg (written commun., 1971). On the other hand, bottom currents seem to be adequate to move very fine sand, silt, and clay-sized particles everywhere in our study area except in the Chukotka Trough, and much of the transport should be as suspended load. The modal size of the suspended sediment samples by McManus and Smyth (1970) is $20 \mu \mathrm{m}$.

The in situ temperature and salinity of highlatitude seas can significantly lessen the settling velocity of a sediment particle with attendant effects on the sediment movement. If one inserts into a settling-velocity equation such as Waddell's (Krumbein and Pettijohn, 1938, p. 104) the approximate average conditions of the coastal water $\left(10^{\circ} \mathrm{C}\right.$, $\left.32^{\circ} / \mathrm{oo}\right)$, the Modified Shelf Water $\left(1^{\circ} \mathrm{C}, 32.5^{\circ} \%\right.$ oo), and the Deep Shelf Water representing winter conditions $\left(-1.75^{\circ} \mathrm{C}, 32.5^{\circ} / \mathrm{oo}\right)$, the settling velocity is only 81,76 , and 72 percent, respectively, of that for standard conditions. The increased viscosity of the cold water, therefore, means that a particle in suspension settles with a smaller effective diameter 


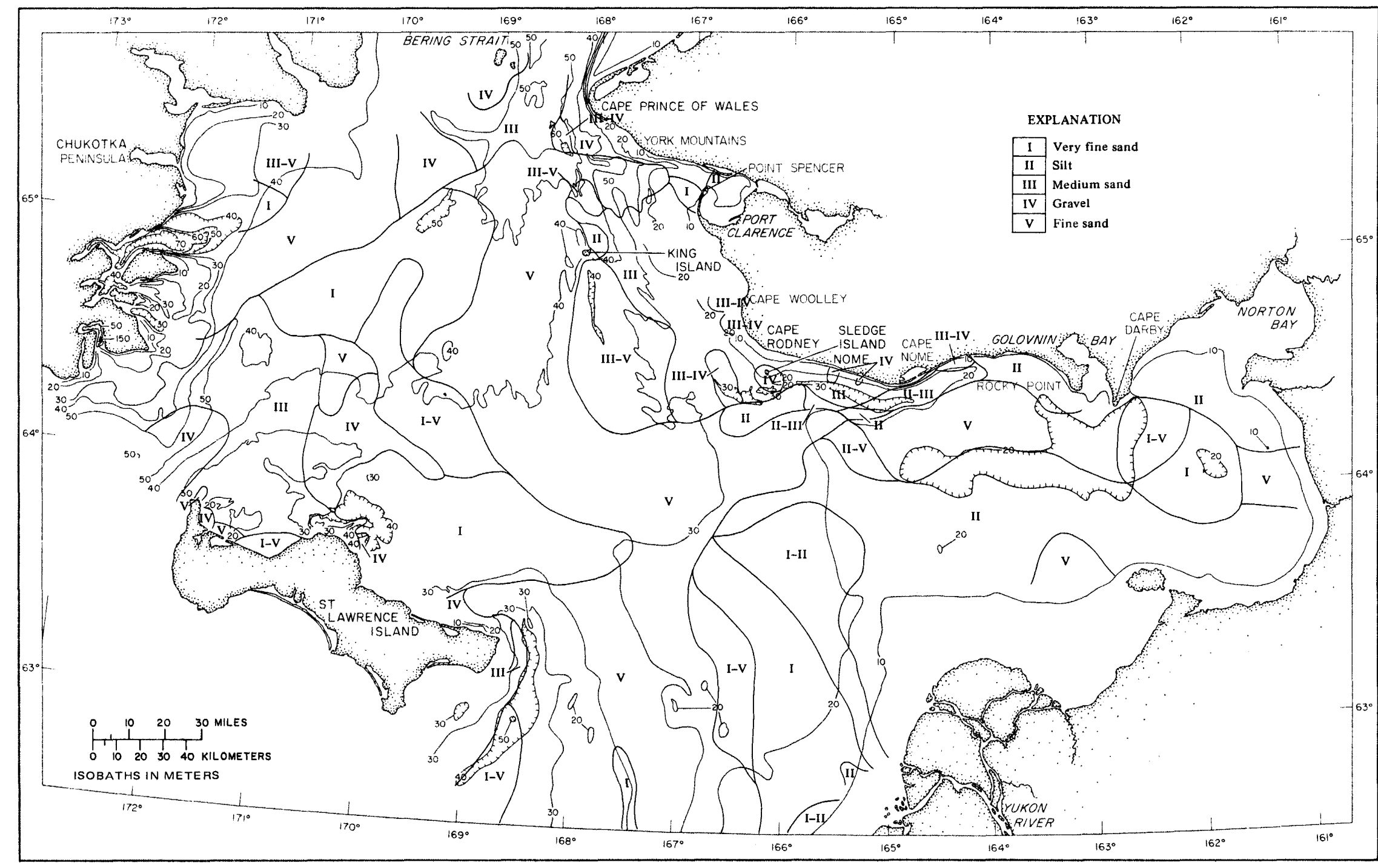

FIGURE 14.-Sediment types determined on the basis of loading values $>0.5$ for $Q$-mode factor analysis. Data for "extreme" samples for each type are presented in table 5 . Note mixtures of sediment types. 
than under standard conditions and, other things being constant, may be more easily transported.

The current measurements near the bottom and in the water column represent many types of motion. Swift, Stanley, and Curray (1971) classify the water motions on a continental shelf as (1) intruding oceanic currents, (2) tidal currents, (3) meteorological currents, and (4) density currents. The most pronounced current in the study area is the northward flow resulting from the slope of the sea surface, which presumably falls into the class of intruding oceanic current. Its dominance is manifest in the lack of a net reversal lasting more than a few days.

The role of tidal currents in the study area is uncertain. At least two waves of semidiurnal period are known, and the number may exceed five (K. Aagaard, written commun., 1970). Two of the several sources of complexities in interpreting these longperiod waves are the similarity in period of certain tidal species and inertial waves at this latitude and the considerable wave reflection that occurs. From the current measurements, it appears that the velocity of the long-period waves is of the same order of magnitude as that of the average current through the region, tens of centimeters per second (K. Aagaard, written commun., 1970). Under certain conditions, then, the tidal currents might double the speed of the water movement, thereby significantly increasing sediment transport, and possibly initiating erosion. Such transport would be in a generally "northward" direction. Under opposite conditions, in opposition to the average northward-setting current, the water movement may be almost stopped, and sediment transport may be greatly reduced.

Few measurements have been made that pertain to meteorological currents. Even the wind measurements are from land stations whose records may be biased by local topography. Assuming that these wind speeds are representative and that over 60-90 percent of the year the winds are 1-16 knots (U.S. Coast and Geodetic Survey, 1964), and assuming reasonable fetch lengths and wind durations, then the deepwater wave characteristics can be calculated, using the method of the U.S. [Army] Beach Erosion Board (1961, p. 16a). From the equation of the maximum horizontal orbital velocity of water particles at the bottom (Shepard, 1963, p. 61), it appears that waves are effective in initiating sediment motion to an average depth of about $20 \mathrm{~m}$, and to greater depths during storms. A residual current or wave drift might thus play a critical role in water less than $20 \mathrm{~m}$ depth, but probably not in the deeper water.
Another type of meteorological current is the wind setup. In the study area, this effect is most evident along the southern coast of Seward Peninsula, where sea level may rise as much as $4 \mathrm{~m}$ and remain at that level for a short period (U.S. Coast and Geodetic Survey, 1964). This rise or setup results from strong southerly winds and is particularly effective here, because it is not only proportional to the shear stress on the water but is inversely proportional to water depth (Wiegel, 1964). Consequently, over the very shallow shelf of northern Bering Sea, the importance of decreasing water depth to the wind setup is greater than usual. The water with its contained sediment piled up against the Seward Peninsula coast must later be removed to the north, as part of the net flow of water toward Bering Strait.

Of the meteorological currents, the most critical in the study area is probably the wind-driven current, as wind-driven currents, or wind drift, can be effective in transporting sediment if the water depth is less than the depth of frictional resistance. If 10 knots is a reasonable estimate of a common wind velocity here (U.S. Coast and Geodetic Survey, 1964), the depth of frictional resistance can be computed as $80 \mathrm{~m}$ (Sverdrup and others, 1942, p. 494), meaning that wind-generated currents probably produce a frictional effect on the bottom throughout the study area. The extent to which this effect would be recorded by the current measurements is unknown, however. Locally, the wind can reverse the northward-setting current and produce southerly water transport for a short time (Husby, 1971).

The density currents in the classification of Swift, Stanley, and Curray (1971) probably are not effective in the study area because the shallow depth permits mixing throughout much of the water column, thereby breaking down stratification, and because of the intensity of the other processes.

A range of conditions is apparent from this discussion, but the greater intensity of processes in the coastal water, particularly along the Seward Peninsula coast, is clear. The north ward transport of water everywhere except in Norton Sound should be reflected in the present-day distribution of sediment.

\section{SEDIMENT DISPERSAL}

Bottom sediments may be classified as modern, relict, or palimpsest (Emery, 1952; Swift and others, 1971). In the Bering Sea, modern sediments are those that consist of material recently introduced into the marine environment and dispersed by present-day currents. Relict sediments consist entirely of material introduced into the sea at some time in the past. 
Palimpsest sediments are a mixture of modern and relict sediments. Recognition of these different types of sediment is commonly facilitated by a study of their biogenic components, as the relict sediment may contain a relict fauna or other evidence of age. R. E. Echols (written commun., 1971) examined Foraminifera in the surface layers of many samples of sediment that we believe on the basis of sedimentological inference to be relict. The fauna consists chiefly of benthic arenaceous forms and seems to be entirely derived from the thriving living population. Relict tests, if present, are completely masked by modern ones. As a result of the relict arenaceous tests being destroyed, removed, or reworked downward in to the sediment, the benthic Foraminifera cannot be used to differentiate relict from modern sediment.

The modern sediments most easily identified in the study area are the silts of southern Norton Sound. Their location near the Yukon Delta, the dominance of silt in the rivers in this climate (Taber, 1943; Lamar, 1966), and the mineralogy of the associated sand suggest a Yukon origin. Moreover, the distribution pattern of the deposit to the north and northwest of the delta can be related to the northwest-setting coastal water, part of which must enter Norton Sound. Although part of the silt may be derived from south of the study area and may be carried into the area in the coastal water (McManus and Smyth, 1970), the Factor II sediment of southern and central Norton Sound is thought to consist mostly of modern Yukon silt (fig. 14).

The R-mode factor analysis of phi sizes suggests that the $3.5,4.0$, and $5 \phi$ classes might be geologically related to one another. Accordingly, if the $5 \phi$ sediment in southern Norton Sound is modern Yukon silt, then possibly the Factor I sand west of the silt (fig. 14) representing $3.5 \phi$ and $4.0 \phi$ sand is modern Yukon or Alaskan Coastal Water sand. The mineralogy of the Factor I sand (I) is the same as that of the sand in the adjacent Yukon silt area (II), implying the same origin (fig. 13). There is an apparent textural gradation in a "downstream" direction into Norton Sound from sand (I), through mixed sand and silt (I and II), into silt (II) inside the sound (fig. 14). Finally, the modern age of this very fine sand (I) is suggested by the good sorting (fig. 10). The west edge of this sand coincides approximately with the western margin of the Alaskan Coastal Water. The northward velocities of $30-40 \mathrm{~cm} / \mathrm{sec}$ in this water (McManus and Smyth, 1970) are competent to transport this very fine sand from the main mouth of the Yukon River near the south edge of our area or from farther south. In the process, a smooth topography is being formed.

The sands underlying the Shpanberg Strait have the same mineral assemblage as these very fine sands (fig. 13). The fine sands in the strait (Factor V, fig. 14) are coarser, however, and are formed into ridges and depressions. As the low current velocities $(10 \mathrm{~cm} / \mathrm{sec})$ of the Modified Coastal Water in the strait (McManus and Smyth, 1970) are incapable of transporting this fine sand, presumably it is relict from a time of lowered sea level when the Yukon River extended farther southwest.

The ridges and depressions in Shpanberg Strait are probably relict. The modern current regime there does not appear capable of constructing topography of this sort, although it may be adequate to preserve it. The westernmost depression may be a graben (Grim and McManus, 1970) or a drowned stream valley (D. M. Hopkins, C. H. Nelson, and R. B. Perry, unpub. data, 1970). The other ridges probably were built in shallow water early in the Holocene transgression. A sampling transect across a ridge that crests at about $20 \mathrm{~m}$ shows that sand on the summit is finer than sand on the flanks; if the sediments in the ridge were affected by some present-day process such as wave-stirring, one would expect to find the coarsest sediment on the ridge crest. The summit sand is brown and richer in heavy minerals than the sand on the flanks, suggesting that it has been affected by shoreline processes, probably during the $20 \mathrm{~m}$ stillstand that produced shoreline deposits off Nome (Nelson and Hopkins, 1972) and Point Spencer (Hopkins, 1967).

The main effect of the topography upon modern processes in Shpanberg Strait appears to be a localization of silt deposition in the eastern depression (fig. 6). Nearer the delta, there is a zone in which the relict fine sand ( $\mathrm{V}$ in fig. 14) seems to be mixed with encroaching modern very fine Yukon sand (I, fig. 14), producing a palimpsest sand (I-V, fig. 14).

The Yukon heavy-mineral association characterizes the relict sand in Shpanberg Strait (V), the modern very fine sand to the east (I), and the sand fraction in the silts of southern Norton Sound (II). In northern Norton Sound, however, the sand fraction in the presumed Yukon silt is a mixture of Yukon and southeastern Seward Peninsula associations (fig. 13). This mixture indicates either a mixture of modern sediments from two sources or a spreading of Yukon sandy silt over relict southeastern Seward Peninsula sand. The second interpretation is preferred for the following reasons: (1) where the southeastern Seward Peninsula mineral assemblage is the 
sole compositional type, the sediment is not silt but sand (Factor V, 2.5 and $3.0 \phi$, fig. 14), and (2) this sand $(V)$ is associated with shoals that do not appear to be modern topographic forms and that are probably prevented by wave action from being covered with finer (and modern) sediment. Bioturbation may play some role in the mixing of sediment types.

If the sediments in Norton sound that bear the southeastern Seward Peninsula mineral association are largely relict, then there must be only a thin accumulation of Yukon sandy silt there. This inference is supported by box cores in central Norton Sound that show as little as $20 \mathrm{~cm}$ of Holocene sandy silt overlying subaerial peaty silt or sand (Nelson and others, 1975) and by the low quantities of suspended sediment observed in central Norton Sound by Sharma and others (1974). Consequently, much of the modern Yukon sandy silt observed entering Norton Sound along the southern side must leave it along the northern side, possibly along the pathway marked by the silt distribution in the depression extending from near Golovnin Bay westward past Nome (fig. 2; fig. 14, Factor II). The silt continues northwest of Sledge Island toward King Island (fig. 6). Suspended-sediment measurements by McManus and Smyth (1970) off Nome and in Norton Sound showed that the silt was in suspension in the bottom water and that the bottom water apparently was flushed periodically from northern Norton Sound. The silt extending through the depression and thence northwestward toward King Island is therefore not viewed as a rapidly thickening and laterally expanding blanket of Yukon detritus burying the other sediments but as material temporarily stored, later to be resuspended and moved through this part of the study area by the Alaskan Coastal Water and associated outflow from Norton Sound. Similarly, the northern terminus of the silt near King Island is probably a dynamic boundary related to increasing current velocities approaching the constriction of Bering Strait.

Heavy-mineral analysis of the $2.75-4.00 \phi$ sand fraction from the body of silt between Nome and King Island shows a southwestern Seward Peninsula metamorphic association (fig. 13). Consequently, although the coastal water is transporting Yukon silt through the area, the silt is passing over, and being mixed with, sand that is probably of rather local origin. According to Nelson and Hopkins (1972), glacial material from the metamorphic terrane on land or from submarine outcrops must be near the surface of the Cape Rodney Parallel Valley Area. This interpretation is supported by the gravel lithology, by the high content of heavy minerals, and by the metamorphic heavy-mineral assemblage. Apparently, the strong northward-setting current has prevented the glacial or bedrock metamorphic material from being buried by the Yukon sediment. The result is a coarse-grained relict sand and gravel that has been made into a lag deposit forming the Cape Rodney Parallel Valley topography beneath the strong current of the Alaskan Coastal Water. Where the modern Yukon silt is mixed with relict sand, a palimpsest sediment is being formed.

Studies of bottom sediments in the Chukchi Sea indicate that the Yukon silt continues moving northward through Bering Strait (McManus and others, 1969). The silt being transported along the western flank of Prince of Wales Shoal was studied by McManus and Creager (1963) and was recently analyzed in relation to current measurements within $1 \mathrm{~m}$ of the bottom (R. W. Sternberg, written commun., 1971). The relict coarse sand and gravel in the strait, whether from bedrock or till, have been formed into a lag sediment by the scouring action of the current through the strait. The rest of the gravel deposits in the Chirikov Basin-for example, those north and northwest of St. Lawrence Island- appear to be moraines or winnowed moraines.

The sediment covering Gambell Shoal is assumed to be relict because it consists of poorly sorted coarse sand of mineralogy similar to nearby relict gravel derived from Chukotka; there is no modern source introducing coarse sand in this area. A relict beach deposit, formed when sea level was lower, is found at depths of 36-38 m on the western flank of Gambell Shoal. It consists of brown well-rounded sand and gravel and weathered shell fragments.

Except at the margins of Gambell Shoal, the sands of the Chirikov Ramp are either fine sand (V, fig. 14) or very fine sand (I). Both have a Chukotka association of heavy minerals, light minerals, and clay minerals. The fine sand (V) occupies most of the Chirikov Ramp. As there appears to be little chance of this sediment coming from Chukotka at present, it is assumed to be relict. To the northeast, this fine sand derived from Chukotka (V) gives way to sand with a southwest Seward Peninsula heavy-mineral assemblage (III). The change in heavy-mineral associations is along the boundary between the Chirikov Ramp and the Cape Rodney Parallel Valley Area. This change in topography, sediment texture, and heavy-mineral composition is best correlated with the average location of the boundary between the Alaskan Coastal Water and Modified Shelf Water. The coastal water, where currents are stronger, overlies the parallel ridges and swales mantled by the southwest Seward Peninsula medium sand, and 
the Modified Shelf Water overlies the finer Chukotka sediment in which the subdued topography of the Chirikov Ramp is developed. Although there is a gradation of sediment texture across the boundary from one topographic province to the other, there is no mixing of heavy-mineral associations (fig. 13).

The poorly sorted very fine sand (I) in the flat bottom of the Chukotka Trough is considered to be relict because of the low current velocities there. Farther north, the current speed has to increase, and this may be reflected by the change to a coarser grained sand despite increased depth of the trough.

The nature of the low ridge in the Norton Plain north of eastern St. Lawrence Island is enigmatic. The sediment texture, topography, and geometry suggest that the ridge is a modern feature with a cover of modern sediment. Yet the heavy-mineral, light-mineral, and clay-mineral assemblages and the physical oceanography suggest that the surface feature and the sediment are relict. No determination can be made at this time.

The Yukon sand, whether modern or relict, cannot be recognized northwest of a line from the eastern tip of St. Lawrence Island to Sledge Island. We considered three possible explanations for the absence of Yukon sand from the Chirikov Basin: (1) The Yukon sand may have been once present, but subsequently flushed out of the Chirikov Basin by strong bottom currents. This seems unlikely, because the areas that lack Yukon sand are characterized by relatively weak bottom currents. (2) The Yukon sand may be younger than the relict sediment of the Chirikov Basin and may have advanced northwestward only to its present boundary along a line extending from eastern St. Lawrence Island to King Island. If this proves to be so, it will imply that the mouth of the Yukon River has been located in its present position for only a short time and that the river previously entered the sea farther south. (3) The boundary that we have drawn between the Yukon and the Chukotka sands may be artificial, merely reflecting increasing difficulty in distinguishing the two heavy-mineral associations with increasing distance of transport. Further knowledge of the sediments of the Chirikov Basin will be required before we can choose between the last two of these possible explanations.

The second explanation seems to be the better, because recent studies indicate that the mouth of the Yukon River lay 80 to $160 \mathrm{~km}$ south of its present position during early Holocene time. Displacement of the outlet to its present position occurred no earlier than 6,200 years ago (Nelson and Creager, 1977) and possibly as recently as 1,200 years ago (Dupre, 1977).

\section{SUMMARY AND CONCLUSIONS}

Study of the bottom sediments in the northern Bering Sea has provided information on sediment texture as it relates to sedimentary processes and on sand mineralogy and pebble lithology as they relate to provenance and relative age of the sediments. From this information, we can map sediment distribution and tentatively define ancient and modern pathways of dispersal (fig. 15).

The largest area covered by modern sediment is adjacent to the Yukon delta in southern Norton Sound. Here the sediment is principally silt with some very fine sand and clay-sized material. The distribution pattern is controlled by the northwardsetting Alaskan Coastal Water and the Yukon runoff, but the exact effects of these currents and other processes acting upon the sediment have not been measured. The part of the coastal current that crosses the mouth of Norton Sound has higher velocities than the part entering the cul de sac. Correlative with this, the coarser part of the modern Yukon sediment lies across the mouth of the sound, the finer material inside. The coarsest modern Yukon sediment is a very fine sand. Along its western boundary, this modern sand is being mixed with a coarser relict Yukon sand to form a palimpsest sediment ( 1 in fig. 15). ${ }^{5}$

The Yukon silt covers much of Norton Sound. Except near the delta, however, the silt deposit appears to be relatively thin. If, as suggested by Lisitsyn (1966), the Yukon River supplies 90 percent of the sediment entering the Bering Sea, then the accumulation rate (depositional rate less resuspension rate) must be low, although it has not been measured. The presence of a large area of relict sand in Norton Sound suggests that velocities of wave and wind drift, tidal currents, and flow associated with the coastal water are intense enough to keep in suspension much of the silt and to flush it from the sound into the main part of the coastal current. At times, some of the silt moves directly across the mouth of Norton Sound (Hooper, 1884, p. 20; Sharma and others, 1974; Nelson and others, 1975) and does not enter the sound at all. Part of the sediment appears to pass through Norton Sound, then exit through a depression on the north side in which Yukon silt forms modern and palimpsest deposits.

\footnotetext{
${ }^{5}$ It should be noted that an alternative explanation for the origin of the very fine sand is that at the present time it is being formed into a deposit by the unmixing of the relict sand. The relict sand, instead of the Yukon River, would be the proximate source of the very fine sand. This is thought to be an unlikely explanation, however, because the very fine sand appears to be associated with the coastal water that has velocities appropriate for its transport. An extended series of measurements on transport of the very fine sand is needed.
} 


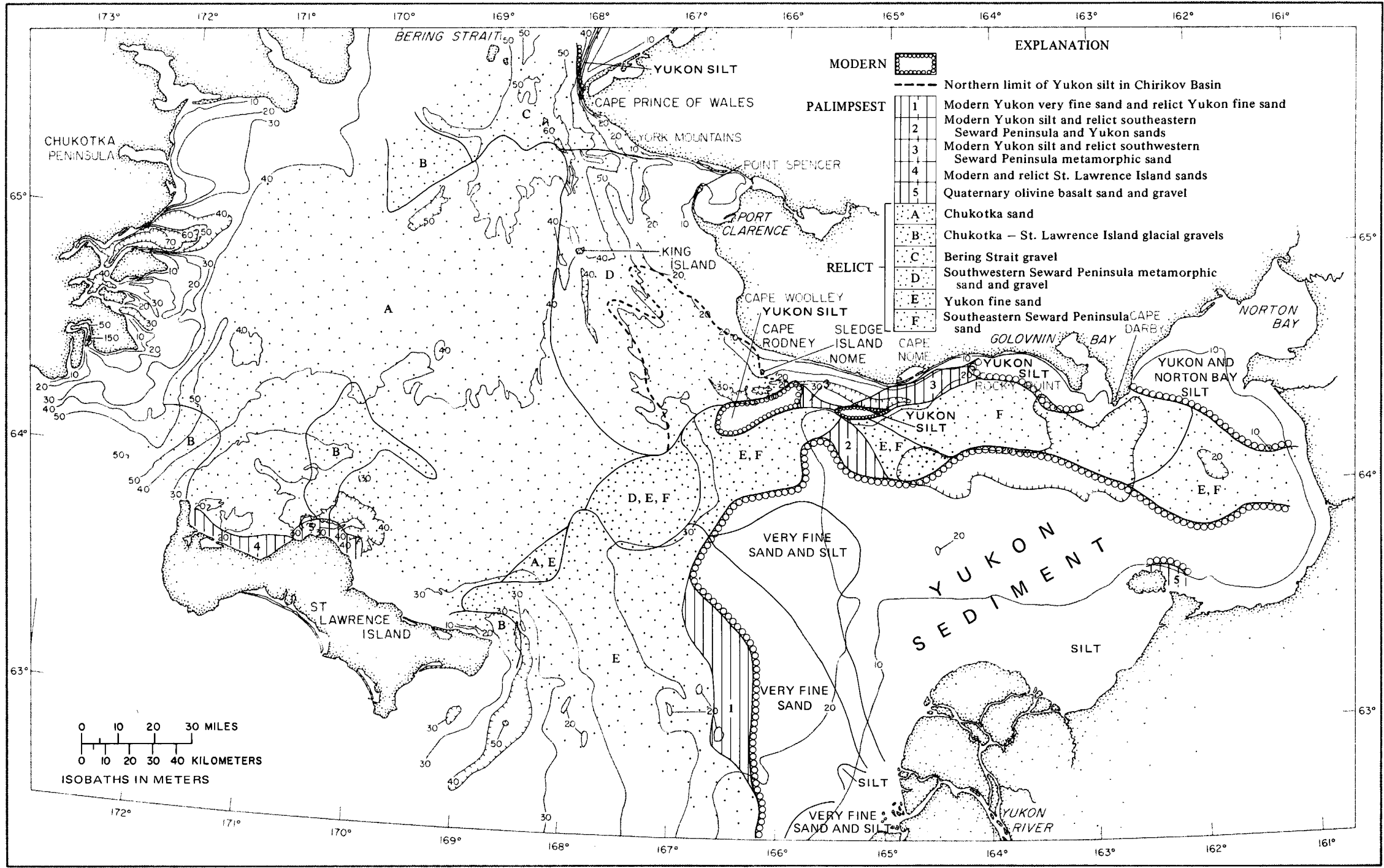

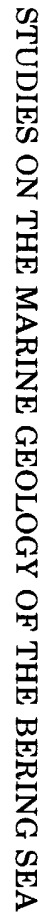

FIGURE 15.-Bottom-sediment distribution from McManus, Venkatarathnam, Hopkins, and Nelson (1974). Relict sediments may include residual material. 
On a secular scale, the silt in this depression may represent a steady-state condition between deposition and erosion. Yukon silt is a component of the bottom sediment as far north as the dashed line in figure 15 , but we do not consider the small percent of silt in this relict sand sufficient to classify the sediment as palimpsest. The minor silt component here underlies high-speed currents that are probably capable of moving most of the modal sands. The silt fraction must be a very dynamic part of the bottom sediment and certainly does not represent the leading edge of an area of net silt accumulation. Farther north, the silt is kept in suspension and forms a high concentration where the coastal water is constricted by Bering Strait. Silt again becomes the dominant sediment size along the western margin of Prince of Wales Shoal, which extends into the Chukchi Sea.

The Yukon silt is clearly the most dynamic sediment in the study area. Yet no measurements of its transport are available. What portion is transported across the mouth of Norton Sound and what portion enters the sound? What is the effectiveness of resuspension of silt in southern Norton Sound? What is the distribution of suspended silt over relict sand areas within the sound? What proportion of the silt issuing from the sound accumulates in the northern depression and what is the residence time of a silt particle if the deposit in the depression is in steady state? What is the nature of the movement of the silt by the high-speed coastal current in the Cape Rodney Parallel Valley Area? With answers to these questions, more knowledge of the sedimentary environments would be available for at least the 3-month icefree season. The nature of sediment transport during the ice-covered season is unknown.

Most of the palimpsest sediment consists of modern Yukon detritus mixed with older sediment, but there are two types of palimpsest sediment that appear to be unrelated to Yukon sediment. Modern' and relict sands near western St. Lawrence Island appear to be mixed by some undefined process. The modern and relict Quaternary basalt sand and gravel are indistinguishable and hence are classified as palimpsest. Relative to the modern Yukon sediment supply, the modern components of other palimpsest sediments is insignificant.

Relict sediments cover the Chirikov Basin, and indeed most of the study area. As neither their relative nor their absolute age is known, however, we can draw only tenuous inferences about the sedimentologic history.

In Shpanberg Strait there is a relict fine-grained Yukon sand that has been formed into depressions and ridges whose crests lie at the level of the $20-\mathrm{m}$ shoreline. Along the margins of this area, the sand has been mixed with other relict sands at the time of deposition or later. The results of a single series of near-bottom current measurements indicate that the mixing may not be occurring today. These measurements also indicate that the current speeds over the relict sand in Shpanberg Strait are sufficient to prevent an accumulation on the bottom of the silt particles that are passing in suspension. Presumably this condition obtains for the other areas of relict sands, but measurements have not been made.

The relict southwest Seward Peninsula metamorphic sand and gravel (Unit D, fig. 15) lies in a region in which currents are probably adequate to resuspend the modal-sized sands. The extremely poor sorting is produced largely by an admixture of Yukon silt. The boundary between the southwest Seward Peninsula sand and the Chukotka sand to the west is exceptionally sharp; the textural and mineralogical boundary coincides with a topographic boundary that probably represents the mean position of the western edge of the strong coastal current. It seems that the coastal current has left a relict or residual lag deposit in a streamlined topography developed on glacial material or on bedrock. Measurements of sediment transport are needed in the Cape Rodney Parallel Valley Area to verify this hypothesis.

Relict or residual gravel appears to be derived from bedrock, glacial till, or moraines. Most of the gravel in the Chirikov Basin is a lag deposit on glacial drift derived from Chukotka. Modern ice-rafted pebbles form a significant component of the sediment only near the shore (Nelson and Hopkins, 1972).

The relict sediments of the Chirikov Basin contain no evidence that Yukon sediment has ever accumulated there nor that the river formerly drained through the basin into the Chukchi Sea. The relict Yukon sands are found only east of a line from eastern St. Lawrence Island to Nome, and the modern Yukon sands are even more restricted in area. Either the characteristics of the Yukon sands are soon lost during transport on the shelf, or the mouth of the Yukon River has lain in its present northern position for only a brief period. Migration of the river mouth seems likelier (Knebel and Creager, 1973; McManus and others, 1974).

A seaward decrease in grain size is commonly accepted as a criterion for recognizing a deposit of modern, as distinguished from relict, sand-that is, of sand being derived from the adjacent shore. The westward fining of sediment from the shallow water near Seward Peninsula to the relatively deep water in the Chukotka Deranged Area might be so inter- 
preted, but the sediment is too coarse to be supplied from the shore at this time; it is therefore relict rather than modern sand. Moreover, the heavy minerals in this relict sand are from source rocks in two areas: the relict sand in the deeper water was derived from Chukotka, that in the shallow water from Seward Peninsula. Although the grading in the relict sand might have been produced by nearshore processes migrating across the area with changes in sea level, this does not seem likely because similar size grading is not present elsewhere-for example, off St. Lawrence Island. Rather the size grading seems to have been produced by the presence, now, of the strong northward-setting current along southwestern Seward Peninsula. This current would have a bottom Ekman effect such as that measured in the Bering Strait by Coachman and Aagaard (1966) that would result in northward transport along the bottom at a small angle to the isobaths and left or seaward rather than paralleling the isobaths. By this current, the sediment could be transported seaward. Such a condition for the continental shelf off Washington is described by Smith and Hopkins (1972). The seaward decrease in current velocity off Seward Peninsula would produce a gradient in transport competency, and probably a similar gradient in grain size. Measurements of sediment transport are needed to test the hypothesis of producing seaward fining of relict sand by present-day processes.

\section{REFERENCES CITED}

Blatt, Harvey, 1967, Provenance determinations and recycling of sediments: Jour. Sed. Petrology, v. 37, p. 1031-1044.

Coachman, L. K., and Aagaard, K., 1966, On the water exchange through Bering Strait: Limnology and Oceanography, v. 11, p. 44-59.

Coachman, L. K., Aagaard, K., and Tripp, R. B., 1975, Bering Strait, the regional physical oceanography: Seattle, Univ. Washington Press, $186 \mathrm{p}$.

Coachman, L. K., and Tripp, R. B., 1970, Currents north of Bering Strait in winter: Limnology and Oceanography, v. 15, p. 625-632.

Creager, J. S., and McManus, D. A., 1967, Geology of the floor of Bering and Chukchi Seas-American studies, in Hopkins, D. M., ed., The Bering land bridge: Stanford, Calif., Stanford Univ. Press, p. 7-31.

Dixon, W. J., 1970, Biomedical computer programs: California Univ. Pubs. Automatic Computation 2, 600 p.

Dupre, W. R., 1977, Yukon Delta coastal processes study, in Assessment of the Alaskan Continental Shelf: U.S. Natl. Oceanog. Atmospheric Admin. and U.S. Bur. Land Management Principal Investigators Rept. Year ending March 1977 (in press)

Emery, K. O., 1952, Continental shelf sediments of southern California: Geol. Soc. America Bull., v. 63, p. 1105-1108.

Fleming, R. H., and Heggarty, D., 1966, Oceanography of the southeastern Chukchi Sea, in Wilimovsky, N. J., and Wolfe,
J. M., eds., Environment of the Cape Thompson region, Alaska: U.S. Atomic Energy Comm., Washington, D.C., p. $697-754$.

Folk, R. L., and Ward, W. C., 1957, Brazos River Bar-a study in the significance of grain-size parameters: Jour. Sed. Petrology, v. 27 , p. 3-26.

Grim, M. S., and McManus, D. A., 1970, A shallow seismicprofiling survey of the northern Bering Sea: Marine Geology, v. 8, p. 293-320.

Hooper, C. L., 1884, Report of the cruise of the U.S. Revenue Steamer Thomas Corwin in the Arctic Ocean, 1881: Washington, D.C., U.S. Govt. Printing Office.

Hopkins, D. M., 1967, Quaternary marine transgressions in Alaska, in Hopkins, D. M., ed., The Bering land bridge: Stanford, Calif., Stanford Univ. Press, p. 47-90.

Hopkins, D. M., Nelson, C. H., and Grim, M. S., 1969, Extent of glaciation on the floor of northern Bering Sea [abs.]: Internat. Quaternary Assoc. (INQUA) Cong., 8th, Paris 1969, Resumées des Communications, p. 209.

Hopkins, D. M., Nelson, C. H., Perry, R. B., and Alpha, T. R., 1976, Physiographic subdivisions of the Chirikov Basin, northern Bering Sea: U.S. Geol. Survey Prof. Paper 759-B, 7 p.

Hopkins, D. M., Rowland, R. W., and Patton, W. W., Jr., 1972, Middle Pleistocene mollusks from St. Lawrence Island and their significance for the paleo-oceanography of the Bering Sea: Quaternary Research, v. 2, p. 119-134.

Husby, D. M., 1971, Oceanographic investigations in the northern Bering Sea and Bering Strait, June-July 1968: U.S. Coast Guard Oceanog. Rept. 40, Washington, D.C., 50 p.

Imbrie, John, and van Andel, Tj. H., 1964, Vector analysis of heavy-mineral data: Geol. Soc. America Bull., v. 75, p. 11311156.

Kelley, J. C., 1971, Mathematical analysis of point count data, in Carver, R. E., ed., Procedures in sedimentary petrology: New York, John Wiley, p. 407-425.

Kelley, J. C., and McManus, D. A., 1969, Optimizing sediment sample plans: Marine Geology, v. 7, p. 465-471.

-1970, Hierarchical analysis of variance of shelf sediment texture: Jour. Sed. Petrology, v. 40, p. 1335-1339.

Knebel, H. J., and Creager, J. S., 1973, Yukon River; evidence for extensive migration during the Holocene transgression: Science, v. 179, p. 1230-1232.

Krumbein, W. C., and Pettijohn F. J., 1938, Manual of sedimentary petrography: New York, Appleton-Century-Crofts, 549 p.

Lamar, W. L.,.1966, Chemical character and sedimentation in the waters, in Wilimovsky, N. J., and Wolfe, J. M., eds., Environment of the Cape Thompson region, Alaska: U.S. Atomic Energy Comm., Washington, D. C., p. 138-148.

Lisitsyn, A. P., 1966, Recent sedimentation in the Bering Sea: U.S.S.R. Acad. Sci., Inst. Oceanology (English Translation: Israel Program for Scientific Translations), 1969, $614 \mathrm{p}$.

McIntyre, D. B., 1963, Precision and resolution in geochronometry, in Albritton, C. C., Jr., ed., The fabric of geology: Palo Alto, Calif., Addison-Wesley Pub. Co., p. 112-134.

McManus, D. A., and Creager, J. S., 1963, Physical and sedimentary environments on a large spit-like shoal: Jour. Geology, v. 71, p. 498-512.

McManus, D. A., Kelley, J. C., and Creager, J. S., 1969, Continental shelf sedimentation in an Arctic environment: Geol. Soc. America Bull., v. 80, p. 1961-1983.

McManus, D. A., and Smyth, C. S., 1970, Turbid bottom water on the continental shelf of the northern Bering Sea: Jour. Sed. Petrology, v. 40, p. 869-873.

McManus, D. A., Venkatarathnam, Kolla, Hopkins, D. M., and Nelson, C. H., 1974, Yukon River sediment of the northern- 
most Bering Sea shelf: Jour. Sed. Petrology, v. 44, p. 10521060 .

Moll, R. F., 1970, Clay mineralogy of the Bering Sea shallows: Univ. Southern California Rept. USC-GEOL 70-2, 101 p.

Nelson, C. H., and Creager, J. S., 1977, Displacement of Yukonderived sediment from Bering Sea to Chukchi Sea during Holocene time: Geology, v. 5, p. 141-146.

Nelson, C. H., and Hopkins, D. M., 1972, Sedimentary processes and distribution of particulate gold in the northern Bering Sea: U.S. Geol. Survey Prof. Paper 689, 27 p.

Nelson, C. H., Hopkins, D. M., and Ness, G., 1969, Interpreting complex relict and modern sedimentation patterns on the Bering shelf: Geol. Soc. America Abs. with Programs 1969, v. 1 , no. 7 , p. 159 .

Nelson, C. H., Hopkins, D. M., and Scholl, D. W., 1974, Tectonic setting and Cenozoic sedimentary history of the Bering Sea, in Herman, Yvonne, ed., Arctic geology and oceanography: New York, Springer-Verlag, p. 119-140.

Nelson, C. H., Larsen, B. R., and Rowland, R. W., 1975, ERTS imagery and dispersal of Yukon and Kuskokwim River plumes, in Carlson, P. R., Conomos, T. J., Janda, R. J., and Peterson, D. H., eds., Principal sources and dispersal patterns of suspended particulate matter in nearshore surface waters of the northeastern Pacific Ocean; ERTS Final Report: Natl. Tech. Inf. Service Rept., U.S. Dept. Commerce, E-75-10266, p. $26-40$.

Patton, W. W., Jr., 1971, Mesozoic tectonics and correlations in Yukon-Koyukuk province, west-central Alaska [abs.]: Am. Assoc. Petroleum Geologists Bull., v. 54, p. 2500.

Patton, W. W., Jr., and Csejtey, Béla, Jr., 1971, Preliminary geologic investigations of western St. Lawrence Island, Alaska: U.S. Geol. Survey Prof. Paper 684-C, p. C1-C15.

Sauer, J. F. T., Tully, J. F., and La Fond, E. C., 1954, Oceanographic cruise to the Bering and Chukchi Seas, summer 1949; Pt. IV, Physical oceanographic studies: U.S. Navy Electronics Lab. Rept. 416, v. 1, 31 p.

Scholl, D. W., and Marlow, M. S., 1970, Bering Sea seismic profiles, 1969: U.S. Geol. Survey open-file report.

Sharma, G. D., Wright, F. F., Burns, J. J., and Burbank, D. C., 1974, Sea surface circulation, sediment transport, and marine mammal distribution, Alaska continental shelf; ERTS Final Report: Natl. Tech. Inf. Service Rept. E74-10711, 77 p.

Shepard, F. P., 1963, Submarine geology, 2d ed.: New York, Harper \& Row, $557 \mathrm{p}$

Silberman, M. L., 1969, Preliminary report on electron microscopic examination of surface textures of quartz sand grains from the Bering shelf in Geological Survey research 1969: U.S. Geol. Survey Prof. Paper 650-C, p. C33-C37.

Smith, J. D., and Hopkins, T. S., 1972, Sediment transport on the continental shelf off of Washington and Oregon in the light of recent current measurements, in Swift, D. J. P., Duane, D. B., and Pilkey, O. H., eds., Shelf sediment transport; process and pattern: Stroudsburg, Penn., Dowden, Hutchinson, and Ross, p. $143-180$.

Snedecor, G. W., 1956, Statistical methods applied to experiments in agriculture and biology, 5th ed.: Ames, Iowa, Iowa State College Press, 534 p.

Sternberg, R. W., 1971, Measurements of incipient motion of sediment particles in the marine environment: Marine Geology, v. 10, p. $113-119$.

Sundborg, Ä., 1956, The River Klarälven-a study of fluvial processes: Geografiska Annaler, v. 38, p. 127-316.

Sverdrup, H. U., Johnson, M. W., and Fleming, R. H., 1942, The oceans, their physics, chemistry, and general biology: Englewood Cliffs, N.J., Prentice-Hall, 1087 p.

Swift, D. J. P., Stanley, D. J., and Curray, J. R., 1971, Relict sediments on continental shelves-a reconsideration: Jour. Geology, v. 79, p. 322-346.

Taber, Stephen, 1943, Perennially frozen ground in Alaska; its origin and history: Geol. Soc. America Bull., v. 54, p. 14331548.

Tagg, A. R., and Greene, H. G., 1973, High-resolution seismic survey of an offshore area near Nome, Alaska: U.S. Geol. Survey Prof. Paper 759-A, p. A1-A23.

Tilman, S. M., Belyi, V. F., Nikolaevskii, A. A., and Shilo, N. A., 1969, Tektonika Severo-vostoka SSSR (Tectonics of northeastern USSR): Akad. Nauk SSR, Sibirsk. Odel., SeveroVostoch. Nauchno-Issled. Inst., Trudy 33, 78 p. [Translation available from Nat. Translation Center, Chicago].

U.S. Beach Erosion Board, 1961, Shore protection, planning and design: U.S. Army Corps Engineers Beach Erosion Board Tech. Rept. 4, 242 p.

U.S. Coast and Geodetic Survey, 1964, United States Coast Pilot, v. 9, Pacific and Arctic coasts, Alaska-Cape Spencer to Beaufort Sea, 7th ed.: Washington, D.C., U.S. Govt. Printing Office, $330 \mathrm{p}$.

Venkatarathnam, Kolla, 1971, Heavy minerals on the continental shelf of the northern Bering Sea: U.S. Geol. Survey openfile report, $92 \mathrm{p}$.

Wiegel, R. L., 1964, Oceanographic engineering: Englewood Cliffs, N.J., Prentice-Hall, 532 p. 
